\title{
Federal Court Stays And Dismissals In Deference To Parallel State Court Proceedings: The Impact of Colorado River
}

The federal courts have often attempted to define the circumstances in which they can decline to hear a case that meets the jurisdictional requirements. An especially troublesome situation is presented when a federal court action concerns a matter that is the subject of parallel state court proceedings. ${ }^{1}$ A stay or a dismissal of the federal action would avoid friction between state and federal courts, free litigants from the burden of duplicative litigation, promote efficient use of judicial resources, and, in some instances, relieve overcrowded dockets. ${ }^{2}$ In spite of these advantages, the notion

' The terms "parallel proceedings," "duplicative litigation," and "the exercise of concurrent jurisdiction," refer to the simultaneous prosecution of two or more suits in which at least some of the issues and parties are so closely related that the judgment of one will necessarily have a res judicata effect on the other. Res judicata effects are of two types. First, "claim preclusion," as expressed in the rules of merger and bar, renders conclusive a valid and final judgment. If the judgment is in favor of the plaintiff, his claim is extinguished and merged into the judgment, and he may not maintain any further action on his original claim. See Restatement (SEcond) of Judgments $\$ \$ 45(a), 47$ (Tent. Draft No. 1, 1973). Of course, if the judgment is for the defendant the plaintiff's claim is extinguished. See id. $\S \S 45(\mathrm{~b}), 48$. The failure of the defendant to interpose a compulsory counterclaim precludes subsequent action on that claim, even if judgment is for the defendant. See id. $\$ 56.1(2)$. FED. R. Crv. P. 13(a) provides that:

A pleading shall state as a counterclaim any claim which at the time of serving the pleading the pleader has against any opposing party, if it arises out of the same transaction or occurrence that is the subject matter of the opposing party's claim and does not require for its adjudication the presence of third parties of whom the court cannot acquire jurisdiction.

As of the end of 1972 more than 30 states had similar counterclaim rules. Reporter's Note, Restatement (Second) of Judgments $\$ 56.1$ (Tent. Draft No. 1, 1973).

Second, "issue preclusion," or collateral estoppel, makes a judgment conclusive as to any issue actually litigated and determined when that issue was essential to the judgment. See Restatement (SEcond) of Judgments $\$ \S 45(\mathrm{c}), 68$ (Tent. Draft No. 1, 1973). The determination is conclusive in a subsequent action between the parties on the same or a different claim. See id. $\$ 68$.

Although the res judicata effect of a judgment cannot be determined until it is raised in a subsequent suit, see, e.g., Gonzales v. Cassidy, 474 F.2d 67, 74 (5th Cir. 1973), it is usually apparent from the pleadings whether the parties and issues in the two suits are sufficiently overlapping that the suits can be considered duplicative.

2 These concerns have motivated two commentators to suggest amendments to the Judicial Code. See Currie, The Federal Courts and the American Law Institute (pt. II), 36 U. CHI. L. Rev. 268, 335 (1969) (recommending an amendment to provide that a state or federal court stay any action filed if a prior suit concerning substantially the same issues and parties is pending in another court, absent a showing that the second court can more fully decide the controversy); Kurland, Toward a Cooperative Judicial Federalism: The Federal Court Abstention Doctrine, 24 F.R.D. 481 (1959) (proposing an amendment to provide that federal 
persists that plaintiffs whose claims satisfy the jurisdictional requirements have a right to a federal forum, and that federal courts have a correlative obligation to hear all cases falling within their jurisdiction.

Prior to the Supreme Court's 1976 decision in Colorado River Water Conservation District v. United States, ${ }^{3}$ the lower federal courts, in recognition of the inefficiencies of duplicative litigation, liberally granted stays in deference to pending state court proceedings. Development of the stay doctrine in the lower courts was marked by inconsistency and confusion that left the ambit of the power to stay unclear. In Colorado River the Supreme Court acknowledged that federal courts have power to stay proceedings in deference to a parallel state suit in order to promote "wise judicial administration." The Court articulated a balancing test to guide the lower courts in the exercise of the power to stay: stays can properly be granted when "exceptional circumstances" outweigh the obligation to exercise federal jurisdiction. The "exceptional circumstances" language suggests that the Court disapproves the readiness with which the lower courts have granted stays.

This comment first describes the background of the Colorado River decision by canvassing the problems involved in parallel suits, the methods by which these problems are handled by state and federal courts in contexts not requiring an abrogation of federal jurisdiction, the related doctrines of abstention and forum non conveniens, and the development of the power to stay. Second, the Colorado River decision is examined in detail. The third section of the comment attempts to apply the reasoning of Colorado River to other situations in which stays have been thought appropriate, and suggests a framework consistent with that analysis for determining the propriety of a stay.

\section{The Development of the Power to Stay and Related DOCTRINES}

A. Duplicative Proceedings

There are three basic types of parallel or duplicative actions:

courts must stay proceedings if there is a prior state or federal suit pending).

Overcrowded dockets create a hazard that some claimholders will be unfairly delayed or deterred from litigating by the fact that others are able to litigate their controversies in two forums. Cf. Crawford v. Seaboard Coast Line R.R., 286 F. Supp. 556, 557-58 (S.D. Ga. 1968) (to deny a stay in a parallel action would result in delaying other litigants who may have no other available forum).

3424 U.S. 800 (1976). 
repetitive suits, reactive suits, and multiple class proceedings. ${ }^{+} \mathrm{Re}-$ petitive suits are multiple suits on the same claim filed by a plaintiff against the same defendant in two or more forums. The reasons for bringing repetitive suits include harassment, insurance against the risk that the first court will not obtain personal jurisdiction over the defendant, ${ }^{5}$ the benefits of forum shopping, ${ }^{6}$ or simply tactical advantage. ${ }^{7}$ A plaintiff might also file a second action in order to circumvent an adverse ruling in the first suit that does not amount to an adjudication on the merits. ${ }^{8}$

Reactive suits are suits filed by the defendant to the first action against the plaintiff either seeking a declaration that he is not liable to the plaintiff or asserting an affirmative claim that arises out of or is intimately related to the same transaction or occurrence that is the subject of the first action..$^{9}$ Reactive suits are often brought in order to obtain the supposed tactical advantages that inhere in proceeding as a plaintiff, ${ }^{10}$ to take advantage of, or avoid, perceived prejudices of a particular forum, ${ }^{11}$ or to take advantage of choice of

- The repetitive/reactive terminology is taken from Vestal, Repetitive Litigation, 45 Iowa L. REv. 525 (1960); Vestal, Reactive Litigation, 47 Iowa L. REv. 11 (1961). Duplicative class litigation can be either reactive or repetitive. For example, if the defendant in a plaintiff class action sues the plaintiffs as a defendant class, his suit would be considered reactive. When two plaintiff class actions are brought by different named plaintiffs, or an individual's complaint is the subject of a pending class action, the suits are "repetitive" as the plaintiff in the second suit presumably belongs to the class whose rights will be determined in the first action. Repetitive class actions are classified separately as multiple class proceedings because of special considerations not involved in the ordinary repetitive suit. See text and notes at notes 181-199 infra.

s See, e.g., O'Hare Int'l Bank v. Lambert, 459 F.2d 328, 330 (10th Cir. 1972); Bethlehem Steel Corp. v. Tishman Realty \& Constr. Co., 72 F.R.D. 33, 36 (S.D.N.Y. 1976).

- See, e.g., Semmes Motors, Inc. v. Ford Motor Co., 429 F.2d 1197, 1203 (2d Cir. 1970); Mars, Inc. v. Standard Brands, Inc., 386 F. Supp. 1201, 1204 (S.D.N.Y. 1974).

7 Cf. Mottolese v. Kaufman, 176 F.2d 301, 303-04 (2d Cir. 1949) (stay conditioned on use of federal discovery in state court action); Aetna State Bank v. Altheimer, 430 F.2d 750, 758 (7th Cir. 1970) (same). But see Beard v. New York Central R.R., 20 F.R.D. 607, 610 (N.D. Ohio 1957) (defendant not required to answer interrogatories since the plaintiff appeared to be using the federal suit only as a "mere auxiliary forum" to assist in the preparation of the state case).

see, e.g., Graziano v. Pennell, 371 F.2d 761, 764 (2d Cir. 1967) (preclusion order); Beaver v. Borough of Johnsonburg, 375 F. Supp. 326, 328 (W.D. Pa. 1974) (dismissal on ground of laches).

- Another form of reactive litigation is an interpleader action filed after an action has been commenced against the interpleader plaintiff. See FED. R. Crv. P. 22; 28 U.S.C. $\$ \S 1335$, 1397, 2361 (1970). The federal interpleader rules provide for the issuance of an injunction against other suits by the court in which the interpleader action was filed. 28 U.S.C. $\$ 2361$ (1970). Since the injunction effectively eliminates the problems of duplicative litigation, interpleader actions will not be discussed further.

1- See Vestal, Reactive Litigation, supra note 4, at 13-14.

"See, e.g., Caribbean Sales Ass'n v. Hayes Indus., Inc., 273 F. Supp. 598 (D.P.R. 1967), vacated, 387 F.2d 498 (1st Cir. 1968). 
law rules in the second forum that might result in the application of more favorable substantive law..$^{12}$ If the defendant fears that litigation in the plaintiff's chosen forum will proceed too slowly, he might bring a reactive suit in order to have the matter resolved more quickly. ${ }^{13}$ The defendant may seek a federal forum in particular because of advantages provided by federal procedure, ${ }^{14}$ or because he has a defense ${ }^{15}$ or counterclaim ${ }^{16}$ based on federal law.

The third category of duplicative litigation involves class action litigation. Separate class actions or shareholder derivative suits may be brought by different named plaintiffs, representing the same or a similar class, on essentially the same cause of action. ${ }^{17}$ The subject matter of a class action may also be the subject of concurrent individual suits, ${ }^{18}$ or vice versa. Multiple class proceedings often result from the desire of individual class members to control the litigation $^{19}$ or to collect the substantial attorneys' fees awarded the plaintiff in a successful class suit. ${ }^{20}$

\section{B. Stays and Dismissals in Contexts Not Requiring an Abrogation of Federal Jurisdiction}

Courts and legislatures have developed a variety of ways to avoid the waste inherent in parallel proceedings. When the two courts are of the same state, the second action will typically be abated if both suits involve the same parties and subject matter and if the parties' rights can be adequately adjudicated in the first action. ${ }^{21}$ Abatement is, in effect, a dismissal and is available as a matter of right. ${ }^{22}$ If the first suit is pending in the courts of another state or in federal court, the state court in which the parallel action is filed has discretionary authority to stay or dismiss the suit. ${ }^{23}$

12 See, e.g., PPG Industries, Inc. v. Continental Oil Co., 478 F.2d 674, 676 \& nn.3 \& 4 (5th Cir. 1973).

${ }^{13}$ See, e.g., Applegate v. Devitt, 509 F.2d 106 (8th Cir. 1975).

it See note 7 supra.

15 See, e.g., Shareholders Management Co. v. Gregory, 449 F.2d 326 (9th Cir. 1971).

is See, e.g., McGough v. First Arlington Nat'l Bank, 519 F.2d 552 (7th Cir. 1975).

"See, e.g., National Health Fed'n v. Weinberger, 518 F.2d 711 (7th Cir. 1975); Nelson v. Grooms, 307 F.2d 76 (5th Cir. 1962); Georgia Ass'n of Educators v. Harris, 403 F. Supp. 961 (N.D. Ga. 1975) (class actions); Rosenfeld v. Black, 445 F.2d 1337, 1341 n.5 (2d Cir. 1971); Ferguson v. Tabah, 288 F.2d 665 (2d Cir. 1961) (stockholder derivative suits).

I* See, e.g., Hobbs v. Northeast Airlines, Inc., 50 F.R.D. 76 (E.D. Pa. 1970).

19 See Developments in the Law-Class Actions, 89 Harv. L. Rev. 1318, 1414 (1976).

20 See id. at 1604-1618.

${ }_{21}^{2}$ See, e.g., Lee v. Lee, 232 So. 2d 370 (Miss. 1970); Lord v. Garland, 27 Cal. 2d 840, 168 P.2d 5 (1946).

22 See, e.g., Evans v. Evans, 186 S.W.2d 277, 279 (Tex. Civ. App. 1945).

${ }^{23}$ See, e.g., Power Train, Inc. v. Stuver, 550 P.2d 1293 (Utah 1976); McWane Cast Iron 


\section{Priority of suit is usually the controlling factor. ${ }^{24}$}

When both proceedings are in a single federal district court, ${ }^{25}$ the two actions can be consolidated. ${ }^{26}$ When two district courts are involved, duplication can be avoided by transfer and consolidation, ${ }^{27}$ by an injunction issued in one suit to prevent the parties from proceeding in the other, ${ }^{28}$ or by a stay of proceedings pending resolution of the case in the other district. ${ }^{29}$ The case of Semmes Motors, Inc. v. Ford Motor Co. ${ }^{30}$ illustrates the general rule governing both injunctions and stays. The plaintiffs sued Ford in a New Jersey state court, seeking an injunction and a temporary restraining order. Ford removed to federal district court and counterclaimed for amounts paid to Semmes on allegedly fraudulent warranty refund claims. Two months later, Semmes sued on the same cause of action in

Pipe Corp. v. McDowell-Wellman Engineering Co., 263 A.2d 281 (Del. 1970).

Occasionally a state court will enjoin the prosecution of a parallel suit in another state on a showing that the suit was brought in bad faith. See, e.g., O'Loughlin v. O'Loughlin, 6 N.J. 170, 78 A.2d 64 (1951). While some injunctions are issued without a showing of bad faith, see, e.g., Applestein v. United Board \& Carton Corp., 35 N.J. 343, 173 A.2d 225 (1961), state courts are generally reluctant to enjoin in personam suits. See Comment, Anti-Suit Injunctions Between State and Federal Courts, 32 U. CHI. L. REv. 471, 478-80 (1965). See generally Dumbauld, Judicial Interference with Litigation in Other Courts, 74 Dick. L. Rev. 369, 38182 (1970). State courts are without power to enjoin proceedings in federal courts, Donovan v. City of Dallas, 377 U.S. 408 (1964). Federal injunctions against state proceedings are governed by the Anti-Injunction Act, 28 U.S.C. $\$ 2283$ (1970), and the Supreme Court has held that federal courts should not enjoin a concurrent state in personam suit, Kline v. Burke Constr. Co., 260 U.S. 226 (1922).

24 See, e.g., Henry v. Stewart, 203 Kan. 289, 454 P.2d 7 (1969); Conrad v. West, 98 Cal. App. 2d 116, 219 P.2d 477 (1950).

Several states have codified the practice of stays and dismissals of subsequently filed suits. See, e.g., Ark. Stat. Ann. 27-1115 (1947); Cal. Crv. Proc. Code $\S 430.10$ (West 1973); Ga. Code ANn. \$ 3-607 (1975); Ill. Rev. Stat. ch. 110, § 48(1)(c) (1975). N.Y. Civ. Prac. Rule 3211(a)(4) (McKinney 1970), New York's statute, provides that a party may move to dismiss a cause on the ground that "there is another action pending between the same parties for the same cause of action in a court of any state or the United States," and that on such a motion the court "may make such order as justice requires."

${ }^{25}$ When a federal court and a federal administrative agency have concurrent jurisdiction over a case, the court can invoke the doctrine of primary jurisdiction to stay or dismiss the suit before it. See generally L. Jaffe, Judicial Control of Administrative Action 121-51 (1965); K. Davis, Administrative Law TeXt 373-81 (1972).

26 FED. R. CIv. P. 42(a).

2728 U.S.C. \$ 1401(a) (1970). See Maxlow v. Leighton, 325 F. Supp. 913 (E.D. Pa. 1971); Winsor v. United Air Lines, Inc., 153 F. Supp. 244, 247 (E.D.N.Y. 1957).

${ }_{2 \pi}$ See, e.g., Telephonics Corp. v. Lindly \& Co., 291 F.2d 445 (2d Cir. 1961); 2 MoORE's Federal Practice ๆ 3.06[2], at 735-36 n.11 (2d ed. 1975).

23 See, e.g., Kerotest Mfg. Co. v. C-O-Two Fire Equip. Co., 342 U.S. 180 (1952); Landis v. North Am. Co., 299 U.S. 248 (1936). The existence of parallel proceedings may justify dismissal of the second suit. See, e.g., Hammett v. Warner Bros. Pictures, Inc., 176 F.2d 145, 150 (2d Cir. 1949). But see id. at 152 (Clark, J., dissenting) (stay or transfer would have been more appropriate).

so 429 F.2d 1197 (2d Cir. 1970). 
federal district court in New York. Ford moved for a stay in the New York action. The district judge denied the motion, but the Second Circuit reversed. Noting that the New Jersey district court could have enjoined the prosecution of the New York action, the court stated that since the requested stay would have the same practical effect as an injunction, the stay motion should be decided under the rule governing injunctions against suit: "Whatever the procedure, the first suit should have priority, 'absent the showing of balance of convenience in favor of the second action. " 31 The court found the plaintiffs' preference for the New York action and their willingness to drop the New Jersey suit an insufficient ground for departing from the priority rule,$^{32}$ noting that instances in which the second court should go forward would be "rare indeed."'33

\section{Federal-State Concurrent Jurisdiction: The Absolute Right Doctrine and Its Decline}

In 1821 the Supreme Court stated in dictum that a federal court has "no right to decline the exercise of jurisdiction which is given." ${ }^{34}$ The statement was repeated in subsequent cases..$^{35}$ In the nineteenth and early twentieth centuries the lower federal courts adhered to this strict rule. ${ }^{36}$ The rationale for the rule was that the jurisdictional statutes grant a plaintiff whose action meets the jurisdictional prerequisites an "absolute right" to bring suit in federal court

\$Id. at 1202 (quoting Remington Prods. Corp. v. American Aerovap, Inc., 192 F.2d 872, 873 (2d Cir. 1951)).

${ }^{32}$ Id. at 1202-03. The Second Circuit considered the fact that Semmes's claims in the New York action based on dealership termination were not before the New Jersey court to be irrelevant, since the dealership termination claims constituted compulsory counterclaims to Ford's counterclaim in the New Jersey action. Id. at 1204.

3 Id. at 1203 . For a description of representative situations that justify departure from the priority rule, see Mattel, Inc. v. Louis Marx \& Co., 353 F.2d 421, 424 n.4 (2d Cir. 1965).

s Cohens v. Virginia, 19 U.S. (6 Wheat.) 264, 404 (1821).

3 McClellan v. Carland, 217 U.S. 268, 282 (1910); Hyde v. Stone, 61 U.S. (20 How.) 170, 175 (1857); Chicot County v. Sherwood, 148 U.S. 529, 534 (1893). In McClellan, the Court stated:

The rule is well recognized that the pendency of an action in the state court is no bar to proceedings concerning the same matter in the Federal court having jurisdiction. . . . [T]he circuit court of the United States had acquired jurisdiction, the issues were made up, and when the State intervened the Federal court practically turned the case over for determination to the state court. We think it had no authority to do this

....

217 U.S. at 282.

${ }_{36}$ See, e.g., Armour \& Co. v. Miller, 91 F.2d 521, 524 (8th Cir. 1937); Checker Cab Mfg. Co. v. Checker Taxi Co., 26 F.2d 752 (N.D. Ill. 1928); Woren v. Witherbee, Sherman \& Co., 240 F. 1013, 1015 (N.D.N.Y. 1917). But see Butler v. Judge, 116 F.2d 1013, 1015 (9th Cir. 1941). 
and place on the court a corresponding obligation to proceed to judgment. ${ }^{37}$ The Supreme Court, however, has held that in certain contexts properly invoked jurisdiction can be abdicated.

1. Forum non conveniens. In Gulf Oil Corp. v. Gilbert, ${ }^{38}$ the Supreme Court held that a federal district court can dismiss an action pursuant to the doctrine of forum non conveniens. Although a strong dissent emphasized the "statutory duty" of a federal court to exercise its jurisdiction, ${ }^{39}$ the majority opinion summarily dismissed this articulation of the absolute right doctrine, stating that the Court "has repeatedly recognized the existence of the power to decline jurisdiction in exceptional circumstances." 10 The doctrine of forum non conveniens formulated in Gulf Oil allows a court in its discretion to dismiss a suit properly before it when a different forum is more convenient for the litigants ${ }^{41}$ or demanded by considerations of public interest. ${ }^{42}$ The application of forum non conveniens does not depend on the existence of a parallel suit; its rationale is that the "necessary generality" of the venue statutes, which are drawn broadly to assure plaintiffs a federal forum, can lead to abuse if plaintiffs "resort to a strategy of forcing the trial at a most inconvenient place for an adversary."

In practice, forum non conveniens seldom deprives plaintiffs of a federal forum. The doctrine "presupposes at least two forums" in which the defendant can be sued, and in the typical case at least one of the alternative forums will be another federal court. When the alternative forum is a federal district court, the case can be transferred to another district or division "for the convenience of parties and witnesses, in the interest of justice." 4 The doctrine of

${ }^{37}$ Checker Cab Mfg. Co. v. Checker Taxi Co., 26 F.2d 752 (N.D. Ill. 1928). The court in Checker $\mathrm{Cab}$ characterized the right to a federal forum as one guaranteed by the Constitution.

330 U.S. 501 (1947).

3. Id. at 513 (Black, J., dissenting).

1. Id. at 504 .

"The Court listed as relevant such factors as "relative ease of access to sources of proof; availability of compulsory process for attendance of unwilling, and the cost of obtaining unwilling, witnesses; possibility of view of premises . . . ; and all other practical problems that make trial of a case easy, expeditious and inexpensive." 330 U.S. at 508.

12 These considerations include "administrative burdens on courts in congested centers; burden of jury duty on the people of a community; local interest in having localized controversies decided at home; appropriateness of having litigation in the state whose law applies so as to avoid conflicts problems or problems of ascertaining foreign law." Id. at 508-09.

Id. at 507.

" 28 U.S.C. $\$ 1404$ (a) (1970). A case can be transferred only to a district court where the original action could have been brought. See Hoffman v, Blaski, 363 U.S. 335, 342-43 (1960) (venue objections cannot be waived by consent). When transfer is possible, a federal court should not dismiss on forum non conveniens grounds. See Collins v. American Automobile Ins. Co., 230 F.2d 416, 418 (2d Cir.), appeal dismissed, 352 U.S. 802 (1956). 
forum non conveniens can make a federal forum unavailable, however, in instances in which the only convenient alternative forum is a foreign tribunal. ${ }^{45}$ Some courts have ruled that a federal court may dismiss even though the only alternative is a state court. ${ }^{46}$ However, the recent revision of the venue statute to provide that an action may be brought in the district "in which the claim arose" 17 makes a convenient federal forum available in all but rare cases.

2. The Abstention Doctrine. Perhaps the deepest encroachment upon the absolute right doctrine has been the development of the abstention doctrine.$^{48}$ Abstention is grounded upon principles of comity and federalism and upon the principle that the federal courts should avoid unnecessary constitutional adjudication. The Supreme Court in Meredith $v$. Winter Haven ${ }^{49}$ insisted that "exceptional circumstances," in the form of "some recognized public policy or defined principle guiding the exercise of the jurisdiction conferred," must be present in order to justify abstention. ${ }^{50}$ Justice Brennan's opinion in Colorado River sets forth a comprehensive categorization of the circumstances in which abstention is appropriate. ${ }^{51}$

The first category, commonly termed Pullman abstention, ${ }^{52}$ applies "in cases presenting a federal constitutional issue which

*s See, e.g., Vanity Fair Mills, Inc. v. T. Eaton Co., 234 F.2d 633, 645 (2d Cir.), cert. denied, 352 U.S. 871 (1956); Del Rio v. Ballenger Corp., 391 F. Supp. 1002, 1004-05 (D.S.C. 1975).

${ }_{16}$ There are very few reported instances of federal court dismissals when the only alternative forum was a state court. See Gross v. Owen, 221 F.2d 94 (D.C. Cir. 1955); Simon v. Silfen, 247 F. Supp. 762 (S.D.N.Y. 1965). At least one court has held that "the doctrine of forum non conveniens does not contemplate a denial of plaintiff's right to bring her action in the federal court." Burns v. Adam, 114 F. Supp. 355, 356 (E.D. Pa. 1953).

$\checkmark 28$ U.S.C. \$ 1391(a)-1391(b) (1970).

"s See generally P. Bator, P. Mishkin, D. Shapiro \& H. Wechsler, Haft \& Wechsler's The Federal Courts and the Federal System 986-1009 (2d ed. 1973); C. Wright, Handbook of the Law of Federal Courts $\$ 52$ at 218-36 (3d ed. 1976); Bezanson, Abstention: The Supreme Court and the Allocation of Judicial Power, 27 VAND. L. REv. 1107 (1974); Field, Abstention in Constitutional Cases: The Scope of the Pullman Abstention Doctrine, $122 \mathrm{U}$. PA. L. Rev. 1071 (1974); Field, The Abstention Doctrine Today, 125 U. PA. L. REv. 590 (1977); Gowen \& Izlar, Federal Court Abstention in Diversity of Citizenship Litigation, 43 TEx. L. REv. 194 (1964).

320 U.S. 228 (1943).

so Id. at 234. The requirement of "exceptional circumstances" has been repeated in subsequent abstention decisions. See, e.g., Harris County Comm'rs Ct. v. Moore, 420 U.S. 77, 83 (1975); Kusper v. Pontikes, 414 U.S. 51, 54 (1973); Lake Carriers' Ass'n v. MacMullan, 406 U.S. 498, 510-11 (1972); Reetz v. Bozanich, 397 U.S. 82, 86 (1970); Zwickler v. Koota, 389 U.S. 241, 248 (1967); Baggett v. Bullitt, 377 U.S. 360, 375 (1964); Propper v. Clark, 337 U.S. 472,492 (1949).

st 424 U.S. at 813-17. Other categorizations have been offered. See, e.g., C. WRIGHT, supra note 48; Bezanson, supra note 48.

52 The leading case is Railroad Comm'n v. Pullman Co., 312 U.S. 496 (1941). 
might be mooted or presented in a different posture by a state court determination of pertinent state law." 53 The parties are usually ordered to repair to state court for a resolution of the state law issues.5 Pullman abstention is ordered only when the state law is unclear..$^{55}$ The rationale underlying this type of abstention is analogous to that underlying the ripeness doctrine: the desire to avoid unnecessarily deciding a constitutional question, ${ }^{56}$ or to "educate" an unavoidable decision by allowing the state court to articulate the relevant state policy and perhaps eliminate certain issues from the case.57

Justice Brennan's second category of abstention, suits presenting "difficult questions of state law bearing on policy problems of substantial public import whose importance transcends the result in the case then at bar," ${ }^{58}$ focuses on cases in which federal adjudication would interfere with an important state governmental function. This "exceptional circumstance" is based on a recognition that adjudication functions in some public law controversies to formulate and articulate state policy, a function more appropriately discharged by the state courts..$^{59}$ Federal court adjudication would be "disruptive of state efforts to establish a coherent policy" in an area entrusted to state regulation and control. ${ }^{60}$

ss 424 U.S. at 814 (quoting County of Allegheny v. Frank Mashuda Co., 360 U.S. 185, 189 (1959)).

st The federal court action is stayed during the state court proceeding. A party is not required to submit his federal claims to the state court but may instead reserve those contentions and return to federal court following the state court's determination of the state law issues. England v. Louisiana State Bd. of Medical Examiners, 375 U.S. 411 (1964).

ss See, e.g., City of Chicago v. Atchison, T. \& S.F. R.R., 357 U.S. 77, 84 (1958). The mere difficulty of ascertaining state law does not ordinarily justify abstention. See Meredith v. Winter Haven, 320 U.S. 228, 234 (1943). Recent cases, however, suggest that if a court can certify the state law questions to the highest state court, abstention is permissible. See Bellotti v. Baird, 428 U.S. 132, 150-51 (1976); Lehman Bros. v. Schein, 416 U.S. 386, 390-91 (1974); United Servs. Life Ins. v. Delaney, 328 F.2d 483 (5th Cir. 1964).

st But see Bezanson, supra note 48, at 1112 (arguing that there is "little reason" not to extend Pullman abstention to any case where the resolution of a state law issue might dispose of a question arising under a federal statute).

37 Bezanson, supra note 48 , at 1112, 1118-19.

s* 424 U.S. at 814.

5t Bezanson, supra note 48, at 1124. Bezanson lists the following characteristics the Court has considered in determining whether the state governmental interest will justify abstention: 1) involvement of "the state's interest in regulating and preserving important natural resources"; 2) the existence of "established state regulatory systems, with a history of state judicial experience reviewing cases arising under that system"; 3) involvement of "areas of traditional state power, such as eminent domain or public education"; and 4) in the absence of an established regulatory system, the existence of a "very high possibility of an intrusive federal adjudication severely handicapping state government." Id. at 1123.

co 424 U.S. at 814. In Burford v. Sun Oil Co., 319 U.S. 315 (1943), the Court held that the district court should have dismissed a suit brought to enjoin enforcement of an administrative order of the Texas Railroad Commission. Texas had established a system of adminis- 
The doctrines of Younger v. Harris ${ }^{61}$ and Huffman v. Pursue, $L t d{ }^{62}$ are the basis of the third branch of abstention, which requires a federal court to dismiss a suit when jurisdiction has been invoked to restrain a state criminal proceeding ${ }^{63}$ or a civil proceeding in which the state has a substantial interest. ${ }^{64}$ The doctrine does not apply if the state proceedings are marked by bad faith, or if the challenged state statute is patently invalid. The justification for declining to exercise jurisdiction in this circumstance is based on principles of equity jurisdiction and considerations of comity and federalism. If the federal plaintiff can assert his federal claim as a defense in the state proceeding, "traditional equity jurisprudence" indicates that a court of equity should not grant relief, since the moving party has an adequate remedy at law. ${ }^{65}$ Federal court inter-

trative decision-making and judicial review to regulate oil production and manage oil and gas fields. The Court held, "[t]hese questions of regulation . . . so clearly involves [sic] basic problems of Texas policy that equitable discretion should be exercised to give the Texas courts the first opportunity to consider them." 319 U.S. at 332. See C. WRIGHT, supra note 48 , at 222 (describing Burford abstention as a self-imposed restraint "to avoid needless conflict with the administration by a state of its own affairs").

B1 401 U.S. 37 (1971).

62420 U.S. 592 (1975). Justice Brennan's categorization of the Younger and Huffman doctrines as abstention doctrines, 424 U.S. at 816, is somewhat novel. See Bartels, Avoiding a Comity of Errors: A Model for Adjudicating Federal Civil Rights Suits that "Interfere" with State Civil Proceedings, 29 StAN. L. REv. 27, 30 n.11 (1976). See generally C. Wright, supra note 48, § 52A; Whitten, Federal Declaratory and Injunctive Interference with State Court Proceedings: The Supreme Court and the Limits of Judicial Discretion, 53 N.C.L. Rev. 591 (1975); Comment, Post-Younger Excesses in the Doctrine of Equitable Restraint: A Critical Analysis, 1976 Duke L.J. 523.

${ }^{83}$ Younger v. Harris, 401 U.S. 37 (1971).

6s Huffman v. Pursue, Ltd., 420 U.S. 592, 603-04 (1975). In Huffman, the Court extended Younger only to federal actions seeking to restrain state civil actions that are "in aid of and closely related to" state criminal proceedings and upheld the dismissal of a $\$ 1983$ action challenging the use of state nuisance statutes to close a pornographic movie theater. But in Juidice v. Vail, 430 U.S. 327 (1977), the Court held that the district court should have dismissed a $\$ 1983$ challenge to civil contempt procedures authorized by New York statutes. The state interest in the "regular operation of its judicial system" was "of sufficiently great import" to require the application of Huffman abstention, regardless of whether the state proceeding was civil, criminal, or quasi-criminal. Id. at 1217. See also Trainor v. Hernandez, 97 S. Ct. 1911 (1977) (Huffman principle is applicable to federal court interference with state civil enforcement action brought by the state in its sovereign capacity).

65 Juidice v. Vail, 430 U.S. 327, 337 (1977); Younger v. Harris, 401 U.S. 37, $43-44$ (1971). See Gerstein v. Pugh, 420 U.S. 103, 108 n.9 (1975) (abstention is inappropriate where challenge raised issue that could not be asserted as a defense in state prosecution).

Suits seeking declaratory judgments concerning the constitutionality of a criminal statute brought by persons threatened with prosecution for its violation are not precluded if no prosecution is pending in state court at the time the federal suit is brought. Steffel v. Thompson, 415 U.S. 452 (1974). Injunctive relief is also available if no state suit is pending. Doran v. Salem Inn, Inc., 422 U.S. 922, 928-29 (1975). But see Hicks v. Miranda, 422 U.S. 332 (1975) (holding that the federal courts must decline to hear civil rights cases that interfere with state 
ference with state proceedings also contravenes the principles of comity, which require that the courts of one sovereignty respect the proceedings of another.$^{66}$ While the application of this branch of abstention to civil proceedings is still unclear, ${ }^{67}$ it appears to be restricted to cases in which the concurrent state proceeding involves important state interests, and in which federal adjudication would impair the state's ability to vindicate those interests. ${ }^{68}$

The abstention decisions substantially limit a litigant's right to a federal court adjudication of his entire civil action. The abstention doctrine, however, does not reflect concern with the problems of duplicative litigation. ${ }^{69}$ In practice, abstention often delays the resolution of suits and results in duplication of effort. ${ }^{70}$

3. Stays in special contexts. Prior to the decision in Colorado River, the Supreme Court recognized a federal court's power to dismiss or stay proceedings in deference to a pending state court action in several limited situations. When both proceedings are in rem or quasi in rem, dismissal of the federal suit is justified by the rule that possession of the res vests the court with the exclusive power to determine all related controversies. ${ }^{71}$ The Court's applica-

prosecutions if the state action was begun before the federal court held "proceedings of substance on the merits," even if the federal suit was filed first).

" The basic principle of comity is that the system of federalism "will fare best if the States and their institutions are left free to perform their separate functions in their separate ways." Juidice v. Vail, 430 U.S. 327, 334 (1977) (quoting Huffman v. Pursue, Ltd., 420 U.S. 592,601 (1975)). Three comity-based concerns are raised when a federal court is asked to interfere with a state criminal proceeding: 1) duplication of effort; 2) negative reflection on the competency of the state court; and 3) disruption of the state's criminal justice system. Bartels, supra note 62 , at 43.

The recognition of a strong policy against duplicative suits in this context would have important implication for parallel jurisdiction problems in a private law context. However, the Court has treated this policy as relatively weak in relation to the other comity concerns. See Doran v. Salem Inn, Inc., 422 U.S. 922, 928-29 (1975); Bartels, supra note 62, at 42 n.76.

"In Vail the Court reserved the question of the applicability of Younger to all civil litigation. Juidice v. Vail, 430 U.S. 327, 336 n.13 (1977).

" The notion of comity, "a proper respect for state functions," Younger v. Harris, 401 U.S. 37, 44 (1971), would seem irrelevant unless the state has some institutional stake in the proceedings. In Vail, the Court emphasized the "State's interest in the contempt process." Juidice v. Vail, 430 U.S. 327, 335 (1977). See Trainor v. Hernandez, 97 S. Ct. 1911, 1920-21 (1977) (Blackmun, J., concurring); Comment, Post-Younger Excesses in the Doctrine of Equitable Restraint: A Critical Analysis, 1976 DukE L.J. 523, 555-58. But see text and notes at notes 169-170, 175 infra.

" With the exception of Younger cases, the abstention doctrine does not require the existence of a parallel state suit.

70 The England doctrine, see note 54 supra, has led to great delays and extensive litigation in cases proceeding under Pullman abstention. See Comment, Abstention: A Case Against Forum-Shuttling, 22 J. PuB. L. 439, 446-49 (1973); Note, Consequences of Abstention by a Federal Court, 73 Harv. L. Rev. 1358 (1960).

"See, e.g., United States v. Bank of New York \& Trust Co., 296 U.S. 463, 477-78 (1936). 
tion of this rule to federal-state concurrent proceeding had two rationales: the principle that the first court must control the res in order "to grant the relief sought," and a comity-based notion that dismissal by the federal court serves "to conciliate the distinct and independent tribunals of the States and of the Union" by preventing the friction that would result from the concurrent exercise of control over the same res. ${ }^{72}$

The Supreme Court has also sanctioned the use of stays in certain admiralty actions. In Langnes $v$. Green, ${ }^{73}$ plaintiff shipowner brought suit in federal district court to establish a limitation of liability pursuant to federal statute. The grant of federal maritime jurisdiction then in effect conferred jurisdiction over admiralty cases, "saving to suitors in all cases the right of a common-law remedy where the common law is competent to give it." 74 The district court enjoined the defendant's concurrent personal injury action in state court and proceeded to judgment, even though the state action had been filed first. The Supreme Court in Langnes ruled that the district court should have stayed itself, because the exercise of federal jurisdiction in such circumstances would interfere with the pending state court action and thus frustrate the purpose of the "savings" clause. ${ }^{75}$

When federal jurisdiction is predicated on the Declaratory Judgment Act ${ }^{76}$ stays in deference to state court proceedings have been approved on the ground that the federal court's assumption of jurisdiction to hear such cases is discretionary. ${ }^{77}$ In the leading case of Brillhart v. Excess Insurance Co. of America, ${ }^{78}$ Justice Frankfurter indicated that the federal court should stay a declaratory judgment action when "another suit is pending in a state court presenting the same issues, not governed by federal law, between the same parties."79

Thus, prior to Colorado River, the Court had approved stays or dismissals in deference to pending state proceedings in certain special situations, but had not articulated any single overarching doc-

${ }^{72}$ Id. at 477 (quoting Taylor v. Carryl, 61 U.S. (20 How.) 583, 595 (1857)).

${ }^{33} 282$ U.S. 531 (1931).

7428 U.S.C. § $41(3)$ (1925), now 28 U.S.C. $\$ 1333$ (1970).

75282 U.S. 531, 541 (1931).

7628 U.S.C. $\$ \S 2201,2202$ (1970).

728 U.S.C. $\$ 2201$ (1970) reads: "In a case of actual controversy within its jurisdiction any court of the United States . . . may declare the rights and other legal relations of any interested party seeking such declaration ...." [emphasis supplied].

7x 316 U.S. 491 (1942).

${ }^{79} \mathrm{Id}$. at 495 . The Court characterized the declaratory judgment action as " $[\mathrm{g}]$ ratuitous interference with the orderly and comprehensive disposition of a state court litigation." 
trine concerning the propriety of stays. ${ }^{80}$ The Court had sanctioned stays in these special contexts, as it had approved stays and dismissals pursuant to the abstention and forum non conveniens doctrines, only because a strong countervailing policy or some specific statutory authorization justified relaxing the obligation of federal courts to exercise their jurisdiction. ${ }^{81}$

\section{The Propriety of Stays: Lower Court Doctrine Before Colorado River}

The lower federal courts have adopted various approaches to the problem of concurrent state and federal actions on the same matter in cases not presenting any of the special circumstances recognized by the Supreme Court as justifying a stay or dismissal. The Tenth Circuit, ${ }^{82}$ and possibly the Third ${ }^{83}$ and Eighth ${ }^{84}$ Circuits, adhere to the view that stays are not justified unless explicitly warranted by Supreme Court precedent. A plurality of the circuits have adopted a broad discretionary standard and have upheld stays in

* Scott v. Germano, 381 U.S. 407 (1965), occasionally considered an abstention case, see Bezanson, supra note 48 , at 1113-14 n.35, is perhaps better viewed as one of the "isolated contexts" in which the Court has approved stays. See D. Currie, Federal CourTs 681-82 (2d ed. 1976); text and notes at notes 212-213 infra. However, Scott did not involve true parallel litigation, as the parties to the two suits were different. Both the state and federal courts had already determined that the apportionment of the Illinois Senate was unconstitutional; the remaining issue was whether the federal court should continue to exercise jurisdiction to ensure enforcement of the judgment.

" Cf. Currie, The Supreme Court and Federal Jurisdiction: 1975 Term, 1976 S. CT. REv. 183, 214-15:

The Court used to say that when a statute gave jurisdiction a court could not refuse to exercise it . . . . The abstention doctrine is basically in conflict with this principle; so is forum non conveniens. The former doctrine, however, generally preserves the right to return to federal court, and the latter to sue in federal court elsewhere. . . . [M] ost of the time the Court at least has been fairly careful to confine the cases in which jurisdiction will not be exercised within fairly narrow and specific categories.

22 See, e.g., United States v. Akin, 504 F.2d 115 (10th Cir. 1974), rev'd, Colorado River Water Conservation Dist. v. United States, 424 U.S. 800 (1976); Miller v. Miller, 423 F.2d 145 (10th Cir. 1970); Lutes v. United States Dist. Ct., 306 F.2d 948 (10th Cir.), cert. denied, 371 U.S. 941 (1962). But see O'Hare Int'l Bank v. Lambert, 459 F.2d 328 (10th Cir. 1972), approving a stay in a repetitive suit in which the plaintiff was uncertain of obtaining personal jurisdiction over the defendant in the first suit and filed the second suit as protection against the expiration of the statute of limitations.

* See Cotler v. Inter-County Orthopaedic Ass'n, P.A., 526 F.2d 537, 542 n.1 (3d Cir. 1975) ("Whether in a case of fully concurrent jurisdiction . . . a stay of the federal case which deprives a litigant of the choice of a federal forum would be proper . . . is an issue we do not here decide."). But see Bechtel Corp. v. Local 215, Laborers' Int'l Union, 544 F.2d 1207, 1215 (3d Cir. 1976) (dictum); Chintala v. Diamond Reo Trucks, Inc., 393 F. Supp. 1392 (E.D. Pa. 1975); Nigro v. Blumberg, 373 F. Supp. 1206 (E.D. Pa. 1974) (the power to stay is within the discretion of the trial court).

* See, e.g., Applegate v. Devitt, 509 F.2d 106 (8th Cir. 1975). 


\section{deference to state proceedings in a variety of circumstances.}

The broad discretionary standard was first announced by the Second Circuit in the landmark case of Mottolese v. Kaufman. ${ }^{85}$ That case came up on a mandamus petition to vacate a district court stay ${ }^{86}$ of a shareholder derivative suit that had been brought while a consolidated action concerning the same claims and substantially the same defendants was pending in state court. Judge Learned Hand's majority opinion relied on the abstention and declaratory judgment decisions to support the assertion that "[t]here can be no doubt . . . that [the notion that there is an absolute privilege of access to federal courts] is no longer true." ${ }^{87}$ Emphasizing the "power inherent in every court to control the disposition of the causes on its docket,"88 the court drew an analogy between the power to stay and the forum non conveniens doctrine ${ }^{89}$ and concluded that an order to stay a federal court action was a matter for

\&s 176 F.2d 301 (2d Cir. 1949).

3 The reviewability of stay orders is no longer a controversial issue. See Note, Appellate Review of Stay Orders in the Federal Courts, 72 CoLum. L. Rev. 518 (1972). The Note's conclusion, that petitions for writs of mandamus under the All Writs Act, 28 U.S.C. $\$ 1651$ (1970), are at present the "most productive channel" for review, is borne out in the caselaw. Some earlier cases limited mandamus to cases not involving the exercise of discretion, thus excluding stay orders from review through the writ, see RCA v. Igoe, 217 F.2d 218 (7th Cir. 1954). This limitation is no longer followed by the lower federal courts. $C f$. LaBuy v. Howes Leather Co., 352 U.S. 249 (1957) (mandamus is available in situations requiring "supervision" of the lower federal courts); Thermtron Products, Inc. v. Hermansdorfer, 423 U.S. 336 (1976) (writ used to order a district court to reinstate a removed case that had been remanded to state court on improper grounds). Use of the writ to review grants of stays is accepted practice in some circuits. See, e.g., Cotler v. Inter-County Orthopaedic Ass'n, P.A., 526 F.2d 537 (3d Cir. 1975); Thompson v. Boyle, 417 F.2d 1041 (5th Cir. 1969), cert. denied, 397 U.S. 972 (1970); Mach-Tronics, Inc. v. Zirpoli, 316 F.2d 820 (9th Cir. 1963). Other approaches to reviewability are used in some situations, such as a finding of effective finality under 28 U.S.C. $\$ 1291$ (1970), see Amdur v. Lizars, 372 F.2d 103 (4th Cir. 1967), and certification under $\S 1292(\mathrm{~b})$, see Lear Siegler, Inc. v. Adkins, 330 F.2d 595 (9th Cir. 1964). See also Hines v. D'Artois, 531 F.2d 726, 729-32 (5th Cir. 1976); Field, The Abstention Doctrine Today, 125 U. PA. L. Rev. 590, 592-601 (1977); AmERICAN Law INSTTTUTE, Study of the Division of Jurisdiction between State and Federal Courts 291-92 (1969).

\$7 176 F.2d at 302.

ss Id. at 303 (quoting Landis v. North American Co., 299 U.S. 248, 254-55 (1936) (holding that a federal district court has power to stay proceedings when a parallel suit is pending in another federal court)).

89 "[W]e can see no difference in kind between the inconveniences which may arise from compelling a defendant to stand trial at a distance from the place where the transactions have occurred, and compelling him to defend another action on the same claim." $176 \mathrm{~F} .2 \mathrm{~d}$ at 303 . The dissent convincingly argued for a clear "difference in kind": relegating the litigant to a state court is easily distinguishable from forcing him to bring another action in a different federal district court. See id. at 307 (Frank, J., dissenting); $c f$. Washington v. General Motors Corp., 406 U.S. 109, 114 (1972), in which the Supreme Court held that the exercise of discretion to decline cases brought under their original jurisdiction was justified in part because of "the availability of the federal district court as an alternative forum." 
the discretion of the trial court. The only issue facing the appellate court was, therefore, whether that discretion had been abused. The court stated that the Supreme Court's abstention decision in Meredith $v$. Winter Haven ${ }^{90}$ required that the defendant show some "positive reason" to stay the federal action. In Judge Hand's view, the mere fact of duplication supplied that reason, for "equity has always interfered to prevent multiplicity of suits." The court saw no reason to prefer the federal suit, since there had been no showing that it would come to trial earlier than the state court action. Because the state court's discovery procedure was inadequate, however, the Second Circuit conditioned the stay on the defendants' consent to the use of the federal discovery rules in the state litigation. ${ }^{92}$

The Mottolese analysis, particularly in its use of Meredith, indicates that the court considered the power to stay pending the termination of state court proceedings to be an aspect of the abstention doctrine. Several later Second Circuit cases make this assumption explicit." Judge Hand equated Meredith's "exceptional circumstances" with a showing of some "positive reason" to support a stay. The Mottolese dissent emphasized that the two formulations were different, arguing that the mere existence of a parallel suit might constitute a "positive reason" to stay but not an "exceptional circumstance." Subsequent cases interpret Mottolese as granting the trial judge substantial discretion in deciding whether to issue a stay..$^{95}$

Three other circuits have recognized a broad discretionary power to stay. In the case of Aetna State Bank $v$. Altheimer ${ }^{96}$ the

* 320 U.S. 228 (1943), discussed at text and notes at notes 49.50 supra.

"176 F.2d at 303 . The equity courts' practice of protecting defendants from vexatious litigation developed shortly after the resolution of the common law equity conflict in 1616. The courts required a defendant to demonstrate hardship beyond the pendency of another action. See Dumbauld, Judicial Interference with Litigation in Other Courts, 74 Dick. L. Rev. 369, 375-83 (1970); Note, Appellate Review of Stay Orders in the Federal Courts, 72 Colum. L. REv. 518, 520-21 (1972). See also 176 F.2d at 307 (Frank, J., dissenting) (the presence of one other suit is a "slim basis" for invoking the multiplicity of suits doctrine).

12176 F.2d at 304 . This aspect of the decision has been criticized as encouraging duplicative actions solely to procure federal discovery and as an unwarranted intrusion on the state legislature's right to prescribe state judicial procedure. See Note, Power to Stay Federal Proceedings Pending Termination of Concurrent State Litigation, 59 Yale L.J. 978 (1950) [hereinafter cited as Yale Note].

's See, e.g., Universal Gypsum of Georgia, Inc. v. American Cyanamid Co., 390 F. Supp. 824 (S.D.N.Y. 1975).

" 176 F.2d at 306 (Frank, J., dissenting).

s See, e.g., Klein v. Walston \& Co., 432 F.2d 936 (2d Cir. 1970); P. Beiersdorf \& Co. v. McGohey, 187 F.2d 14 (2d Cir. 1951).

" 430 F.2d 750 (7th Cir. 1970). Aetna State Bank was overruled in Calvert Fire Ins. Co. 
Seventh Circuit reasoned that the power to stay constitutes an aspect of the abstention doctrine and invoked the "ever increasing workload of our courts" as a basis for viewing a parallel state court proceeding as an "exceptional circumstance." 97 The Fourth Circuit has reached an identical result on similar reasoning..$^{98}$ In Weiner $v$. Shearson, Hammill \& Co ${ }^{99}$ the Ninth Circuit also adopted a broad discretionary standard, but did not rely on an equation of parallel jurisdiction and abstention. ${ }^{100}$ The Weiner court found that the restrictions on the abstention doctrine imposed by the Supreme Court in Meredith $v$. Winter Haven ${ }^{101}$ have no application to stays in cases involving a pending state proceeding, since abstention is not dependent on parallel litigation. ${ }^{102}$ The concerns that counsel against the exercise of concurrent jurisdiction-friction between the courts, waste of judicial resources, burdens on the litigants, and the unseemliness of a race to judgment-are generally absent in cases raising the question of abstention, for abstention operates to "relegat[e] the parties to an as yet uncommenced action in the state courts." 103 The court thought that these distinctive considerations are sufficient to justify a separate doctrine allowing trial courts to stay proceedings pending the resolution of parallel state litigation.

The courts that recognize broad trial court discretion have attempted to identify the factors relevant to the decision whether to stay. ${ }^{104}$ The most significant factors are the similarity of issues and

v. Will, 560 F.2d 792 (7th Cir. 1977). See note 153 infra.

$n 430$ F.2d at 756. Reliance on the crowded dockets of the district courts to justify staying a federal suit is suspect in light of Thermtron Products, Inc. v. Hermansdorfer, 423 U.S. 336, 344 (1976), in which the Court held that a federal district court could not remand a properly removed action to state court on the ground that it was "too busy" to try the case without causing undue delay. See also Ashman, Alfini \& Shapiro, Federal Abstention: New Perspectives on Its Current Vitality, 46 Miss. L.J. 629, 652 (1975).

${ }^{93}$ Amdur v. Lizars, 372 F.2d 103, 106 (4th Cir. 1967). But see Cunningham v. Ford Motor Co., 413 F. Supp. 1101, 1106 (D.S.C. 1976) (apparently limiting Amdur to its facts).

" 521 F.2d 817 (9th Cir. 1975).

${ }^{100}$ Until 1975 the Ninth Circuit denied the existence of a general power to stay, for reasons paralleling the Tenth Circuit's. See, e.g., Lecor, Inc. v. United States Dist. Ct., 502 F.2d 104 (9th Cir. 1974); Mach-Tronics, Inc. v. Zirpoli, 316 F.2d 820, 824-28 (9th Cir. 1963).

101320 U.S. 228 (1943).

102521 F.2d at 820 .

$103 \mathrm{Id}$. at 821.

10 The most comprehensive collection of the factors involved in ruling on stays is in Annot., 5 A.L.R. Fed. 10 (1970). See also 7A C. Wright \& A. Mnler, Federal Practice \& Procedure \$ 1838 (1972); Note, Stays of Federal Proceedings in Deference to Concurrently Pending State Court Suits, 60 CoLuM. L. REv. 684, 698-710 (1960) [hereinafter cited as Columbia Note]; Yale Note, supra, note 92, at 983-91. 
parties in the two suits, ${ }^{105}$ the priority of the actions in time, ${ }^{106}$ the good faith of the litigants, ${ }^{107}$ and the basis of federal jurisdiction asserted. ${ }^{108}$ The courts have generally refused to adopt per se rules, ${ }^{109}$ and instead leave the determination to a balancing of all the factors. ${ }^{110}$

The Fifth Circuit has taken a distinctive approach to the parallel proceedings problem, an approach that rejects both the permissive view endorsed by a plurality of the circuits and the strict conservative view epitomized by the Tenth Circuit. "In Thompson $v$. Boyle, ${ }^{112}$ the court refused to issue a writ of mandamus to vacate a stay pending the disposition of a parallel action in the Louisiana state court. The Fifth Circuit found "compelling reasons" for the

${ }^{105}$ See, e.g., Ferguson v. Tabah, 288 F.2d 665 (2d Cir. 1961); Lyons v. Westinghouse Elec. Corp., 222 F.2d 184 (2d Cir. 1955); Beaver v Borough of Johnsonburg, 375 F. Supp. 326 (W.D. Pa. 1974); Levy v. Alexander, 170 F. Supp. 439 (E.D.N.Y. 1959).

${ }^{108}$ See, e.g., Aetna State Bank v. Altheimer, 430 F.2d 750 (7th Cir. 1970); Universal Gypsum of Georgia, Inc. v. American Cynamid Co., 390 F. Supp. 824 (S.D.N.Y. 1975); Crawford v. Seaboard Coast Line R.R., 286 F. Supp. 556 (S.D. Ga. 1968).

107 See, e.g., Amdur v. Lizars, 372 F.2d 103 (4th Cir. 1967); Mars, Inc. v. Standard Brands, Inc., 386 F. Supp. 1201 (S.D.N.Y. 1974). Some courts apparently feel that repetitive suits are more likely to be brought in bad faith than reactive suits. $C$. Rosenfeld v. Black, 445 F.2d 1337, 1341 n.5 (2d Cir. 1971) (Friendly, J.) ("We unreservedly condemn this practice [filing suits in both state and federal courts] which, for reasons that are well understood, is so frequently utilized in stockholder actions in the Southern District of New York").

${ }^{100}$ If the case is within exclusive federal jurisdiction, the courts are reluctant to grant a stay. See Cotler v. Inter-County Orthopaedic Ass'n, P.A., 526 F.2d 537 (3d Cir. 1975); Simon \& Schuster, Inc. v. Cove Vitamin \& Pharmaceutical, Inc., 211 F. Supp. 72 (S.D.N.Y. 1962). But see Klein v. Walston \& Co., 432 F.2d 936 (2d Cir. 1970); Aetna State Bank v. Altheimer, 430 F.2d 750 (7th Cir. 1970).

Where jurisdiction is predicated solely on diversity of citizenship and only state law issues are involved, the courts are usually receptive to a motion to stay. See, e.g., Lewis v. Dansker, 68 F.R.D. 184, 193 (S.D.N.Y. 1975); Universal Gypsum of Georgia, Inc. v. American Cyanamid Co., 390 F. Supp. 824 (S.D.N.Y. 1975); Nigro v. Blumberg, 373 F. Supp. 1206 (E.D. Pa. 1974); Crawford v, Seaboard Coast Line R.R., 286 F. Supp. 556 (S.D. Ga. 1968).

For a discussion of the relevance of the basis of federal jurisdiction to the decision to grant a stay, see text and notes at notes 215-217 infra.

los But see Universal Gypsum of Georgia, Inc. v. American Cyanamid Co., 390 F. Supp. 824,830 (S.D.N.Y. 1975) (adopting a rule that a district court will order a stay when an instate plaintiff brings a diversity action raising only state law issues and a previously or simultaneously commenced action is pending in the courts of his own state).

110 For example, several courts have granted stays without requiring the parties to be the same or the issues to be identical if the parallel state proceeding will resolve major issues or defenses and facilitate the litigation of the federal suit. See, e.g., Klein v. Walston \& Co., 432 F.2d 936 (2d Cir. 1970); Georgia Ass'n of Educators v. Harris, 403 F. Supp. 961 (N.D. Ga. 1975).

iII Some district courts in the Fifth Circuit apparently use the discretionary standard in ruling on motions to stay. See Georgia Ass'n of Educators v. Harris, 403 F. Supp. 961, 964 (N.D. Ga. 1975); Crawford v. Seaboard Coast Line R.R., 286 F. Supp. 556, 557 (S.D. Ga. 1968).

112417 F.2d 1040 (5th Cir. 1969), cert. denied, 397 U.S. 972 (1970). 
stay, since the federal court could not completely dispose of the matters in controversy. ${ }^{113}$ PPG Industries, Inc. $v$. Continental Oil Co. ${ }^{114}$ further expands this approach. PPG brought a diversity suit in federal district court in Louisiana, seeking a declaration of contractual rights and an injunction restraining Conoco from breaching the contract. ${ }^{115}$ Conoco had previously sued PPG and another major customer in Texas state court for a judgment declaring that it was not in breach of contract. The district court rejected PPG's claim that Meredith $v$. Winter Haven ${ }^{116}$ precluded the federal courts from staying proceedings in deference to a state court action. The court interpreted Meredith as simply affirming "the mandatory nature of diversity jurisdiction ... [and making] clear that in equity suits only 'exceptional circumstances' could justify a discretionary refusal to exercise that jurisdiction."117 Although Meredith had not listed the pendency of a parallel state court action as an exceptional circumstance, its list was not necessarily exhaustive. The court viewed the Supreme Court's decision in Brillhart v. Excess Insurance Co. ${ }^{118}$ as recognizing that the strong policy against duplicative litigation justifies declining the exercise of federal jurisdiction in cases in which the federal action is for a declaratory judgment. Pointing out that injunctive relief, like declaratory relief, is discretionary, ${ }^{119}$ the $P P G$ court concluded that the considerations favoring stays where the federal action is declaratory similarly justify a discretionary power to stay injunctive actions in deference to parallel state proceedings. ${ }^{120}$ The court affirmed the district court's exercise

I13 Id. at 1042.

II 478 F.2d 674 (5th Cir. 1973), noted in 51 Tex. L. Rev. 1252 (1973).

115 Id. at $675-78$. The court noted that the request for injunctive relief distinguished the case from Brillhart v. Excess Ins. Co., 316 U.S. 491 (1942), which held that a federal court had discretion to decline jurisdiction in a declaratory judgment suit when parallel proceedings are pending in state court. $478 \mathrm{~F} .2 \mathrm{~d}$ at 679 . Brillhart is discussed in text and notes at notes 76-79 supra.

118320 U.S. 228 (1943), discussed in text and notes at notes 49-50 supra.

$117478 \mathrm{~F} .2 \mathrm{~d}$ at 678.

118316 U.S. 491 (1942).

113 478 F.2d at 681 (quoting Eccles v. Peoples Bank, 333 U.S. 426, 431, 436 (1948), and Abbott Laboratories v. Gardner, 387 U.S. 136, 148 (1967)).

${ }^{120}$ This conclusion ignores a critical distinction between the declaratory judgment and abstention theories-the exercise of jurisdiction under the Declaratory Judgment Act is expressly discretionary. See note 77 supra; Borchard, Discretion to Refuse Jurisdiction of Actions for Declaratory Judgments, 26 MinN. L. Rev. 677, 692 (1942):

[The] considerations which led to the adoption of the declaratory action, namely, convenience, expediency, need, desirability, public interest or policy . . . necessarily import the employment of discretion, so that as opposed to the general though by no means universal rule in actions at law or in equity, the action for a declaratory judgment 
of the stay power, because the state suit had been filed prior to the federal action, some of the parties to the state suit were not before the federal court, and there was no indication that a stay would be "unfair" to PPG. ${ }^{21}$

Thus, by the time the Supreme Court finally came to consider the power of federal courts to stay themselves in deference to parallel state proceedings, the trend in the lower courts was toward broad stay power. ${ }^{122}$ The lower court decisions had thoroughly explored the possible approaches, and those circuits that recognized a broad power to stay had delineated appropriate considerations to guide its exercise.

\section{Colorado River Water Conservation District v. United STATES}

The stay question reached the Supreme Court in the 1976 case of Colorado River Water Conservation District $v$. United States. ${ }^{123}$ The case was unusual in many respects, and its background deserves detailed explication. The controversy began when the United States brought suit in federal district court seeking a declaration of certain water rights. Federal jurisdiction was based on section 1345 of the Judicial Code, which vests the district courts with original jurisdiction of suits brought by the United States. ${ }^{124}$ The Colorado River Water Conservation District intervened as a defendant in order to file a motion to dismiss, and other intervenors followed. Two months after federal suit was brought, one of the intervenors filed a motion in a state forum, Colorado Water Division $7,{ }^{125}$ seeking to join the United States in proceedings to adjudicate the same

in the federal courts does not lie automatically but only where a useful purpose will be served.

The $P P G$ court expressly refused to decide whether the pendency of a state court action would constitute an exceptional circumstance in a legal action. $478 \mathrm{~F} .2 \mathrm{~d}$ at $681-82$.

$221478 \mathrm{~F} .2 \mathrm{~d}$ at 683 .

122 Besides the Second, Fourth, Seventh, and Ninth Circuits, other courts appear to have implicitly recognized a discretionary power to stay. See Annot., 5 A.L.R. Fed. 10, 30-33 (1970); Jewell v. Davies, 192 F.2d 670 (6th Cir. 1951), cert. denied, 343 U.S. 904 (1952); In re President \& Fellows of Harvard College, 149 F.2d 69 (1st Cir. 1945); Reiter v. Universal Marian Corp., 173 F. Supp. 13 (D.D.C. 1959), vacated as moot, 273 F.2d 820 (D.C. Cir. 1960). 123424 U.S. 800 (1976).

12428 U.S.C. $\$ 1345$ (1970) provides in part: "Except as otherwise provided by Act of Congress, the district courts shall have original jurisdiction of all civil actions, suits, or proceedings commenced by the United States . . . ."

${ }^{125}$ Each of Colorado's seven water divisions determines water claims and administers distribution for one or more of the larger river basins in the state. The statutory scheme is contained in Colorado's Water Rights Determination and Administration Act of 1969. Colo. REv. StaT. §§ 37-92-101 to 602 (1973 \& Supp. 1976). 
water rights involved in the federal suit. The United States was joined as a defendant and served with process pursuant to the McCarran Amendment, ${ }^{126}$ by which the federal government consents to be sued in proceedings for the adjudication or administration of "rights to the use of water of a river system or other source." 227 A motion to dismiss was then filed in the district court, on the ground that the McCarran Amendment precludes federal courts from assuming jurisdiction over water rights cases. The district court did not decide this issue, but granted the motion on abstention grounds.

On appeal the Tenth Circuit reversed, ${ }^{128}$ holding that the McCarran Amendment simply allowed the Government to be joined as a defendant in a state water rights action in which it was a necessary party and did not by implication prohibit the United States from litigating its water rights as a plaintiff in a federal court. ${ }^{129}$ The court also concluded that the district court should not have abstained, emphasizing that the federal action had been filed first and that jurisdiction was based on the presence of the United States as plaintiff. ${ }^{130}$

On certiorari the Supreme Court reversed the court of appeals decision. Although the Court agreed that abstention was inappropriate on the facts of the case ${ }^{131}$ and that the McCarran Amendment

${ }^{126} 43$ U.S.C. $\$ 666$ (1970). The relevant portions of the statute are:

Consent is given to join the United States as a defendant in any suit (1) for the adjudication of rights to the use of water of a river system or other source, or (2) for the administration of such rights, where it appears that the United States is the owner of or is in the process of acquiring water rights by appropriation under state law, by purchase, by exchange, or otherwise, and the United States is a necessary party to such suit. The United States, when a party to any such suit, shall (1) be deemed to have waived any right to plead that the State laws are inapplicable or that the United States is not amenable thereto by reason of its sovereignty, and (2) shall be subject to the judgments, orders, and decrees of the court having jurisdiction, and may obtain review thereof, in the same manner and to the same extent as a private individual under like circumstances ....

${ }_{127} 43$ U.S.C. $\$ 666(a)$ (1970). Consent to suit under the McCarran Amendment applies to the adjudication of the United States' reserved water rights, as well as to rights acquired under state law. See United States v. District Ct., 401 U.S. 520 (1971). Proceedings under Colorado's Water Rights Determination and Administration Act are within the scope of the McCarran Amendment. See United States v. District Ct., 401 U.S. 527 (1971).

128 United States v. Akin, 504 F.2d 115 (10th Cir. 1974).

129 Id. at 118-19.

${ }^{130}$ Id. at 121-22.

131 Abstention was arguably proper because of the presence of "difficult questions of state law bearing on policy problems of substantial public import whose importance transcends the result in the case then at bar," 424 U.S. at 814. See text and notes at notes 58-60 supra. In fact, the parties argued the case on abstention grounds and the briefs did not discuss the parallel proceedings issue. The federal action involved water claims based on both state and 
did not preclude the United States from suing in federal court, ${ }^{132}$ the Court ruled that the district court's dismissal of the action was nonetheless proper. The Court distinguished parallel jurisdiction problems from the considerations underlying the abstention doctrine:

Although this case falls within none of the abstention categories, there are principles unrelated to considerations of proper constitutional adjudication and regard for federal-state relations which govern in situations involving the contemporaneous exercise of concurrent jurisdiction, either by federal courts or by state and federal courts. These principles rest on considerations of "[w]ise judicial administration, giving regard to conservation of judicial resources and comprehensive disposition of litigation." 133

The Court stated that when the parallel action is in a state court, the power to dismiss in deference to the parallel proceeding is limited by the "virtually unflagging obligation of the federal courts to exercise the jurisdiction given them." 134 The circumstances that justify dismissal in deference to a state proceeding must, therefore, be "exceptional," 135 and "the circumstances permitting the dismissal of a federal suit due to the presence of a concurrent state proceeding for reasons of wise judicial administration are considerably more limited than the circumstances appropriate for abstention." ${ }_{136}$ The Court then enumerated factors relevant to the determination of whether "exceptional circumstances" exist, including the friction that attends the exercise by two courts of concurrent jurisdiction over a single res, ${ }^{137}$ the relative inconvenience of the federal forum, ${ }^{138}$ the desirability of avoiding piecemeal litigation, ${ }^{139}$ and the order of

federal law. However, the applicable state law was clear-Colorado applied the doctrine of prior appropriation-and a federal decision on the state claims would not "impair efforts to implement state policy." 424 U.S. at 815 . Although the federal claims might "conflict with similar rights based on state law . . . [the] mere potential for a conflict in the results of adjudications" did not warrant abstention. Id. at 815-16.

132 All nine justices agreed with the Tenth Circuit's analysis.

135424 U.S. at 817 (quoting Kerotest Mfg. Co. v. C-O-Two Fire Equipment Co., 342 U.S. 180,183 (1952)). Kerotest upheld a stay issued in deference to an action pending in another federal district court. The opinion emphasized the "ample degree of discretion . . . [which] must be left to the lower courts." 342 U.S. at 183-84.

is 424 U.S. at 817.

135 Id. at 818 .

is Id.

137 See text and notes at notes 71-72 supra.

13x 424 U.S. at 818 (citing Gulf Oil Corp. v. Gilbert, 330 U.S. 501 (1947), discussed in text and notes at notes 38.47 supra).

131 424 U.S. at 818 (citing Brillhart v. Excess Ins. Co., 316 U.S. 491 (1942), discussed in 
commencement of the respective suits. ${ }^{140}$

In Colorado River the decisive factor in favor of a stay was "[t]he clear federal policy" evinced by the McCarran Amendment: "the avoidance of piecemeal adjudication of water rights in a river system."1+1 The Court analogized the policy of the McCarran Amendment to the basis of the rule that in in rem cases jurisdiction must be yielded to the court that first acquired control over the res. In both in rem and water rights cases, the Court stated, the goal is to avoid "the generation of additional litigation through permitting inconsistent dispositions of property." $1+2$ The opinion noted four additional factors supporting the district court's dismissal: ${ }^{143}$ the federal action had not proceeded beyond the filing of the complaint; "the extensive involvement of state water rights occasioned by this suit"; the distance-300 miles-between the Denver district court and the court in Division 7; and the Government's participation in similar proceedings in other Colorado courts. ${ }^{14}$

In dissent, Justice Stewart, joined by Justices Blackmun and Stevens, agreed that abstention was inappropriate, but viewed that determination as leading "ineluctably to the conclusion that the District Court was wrong in dismissing the complaint." 145 Justice

text and notes at notes $76-79$ supra).

${ }_{140} 424$ U.S. at 818 (citing Pacific Live Stock Co. v. Lewis, 241 U.S. 440, 447 (1916)).

141424 U.S. at 819.

"12 Id. "This concern is heightened with respect to water rights, the relationships among which are highly interdependent." But see text and notes at notes 147-49 infra.

13 Although the Court's discussion never mentions a stay of the federal action as an alternative to dismissal, the analysis is equally applicable to determining the propriety of a stay. The technical distinction that a stay does not involve relinquishing jurisdiction but merely postpones its exercise is of little practical importance. A stay in deference to parallel proceedings will usually have the same effect as a dismissal because of the effects of res judicata. See Calvert Fire Ins. Co. v. Will, 560 F.2d 792 (7th Cir. 1977); PPG Industries, Inc. v. Continental Oil Co., 478 F.2d 674, 682 (5th Cir. 1973); Ashman, Alfini \& Shapiro, Federal Abstention: New Perspectives on its Current Vitality, 46 Miss. L.J. 629, 639 (1975). But see C. WRIGHT, supra note 60, at 228 ("there is enough . . . arguable difference between a stay and a dismissal, that the propriety of this possible fourth abstention doctrine cannot be regarded as finally settled").

Stays are usually preferred over dismissals since the parties can easily reopen the federal suit if the state suit should prove inadequate to resolve the controversy, or if the state judgment leaves issues before the federal court unresolved. In several cases appellate courts have modified the district court's dismissal to provide that the action be stayed. See, e.g., Langnes v. Green, 282 U.S. 531, 541-42 (1931); McGreghar Land Co. v. Meguiar, 521 F.2d 822 (9th Cir. 1975); Aetna State Bank v. Altheimer, 430 F.2d 750, 756 (7th Cir. 1970).

In Colorado River there was no need to leave open the door to the federal court, since there was no danger that the state judgment would not encompass all the issues and parties before the federal court.

14424 U.S. at 820 . The dissent characterized these additional factors as "insubstantial." See id. at 823-24 n.6 (Stewart, Blackmun \& Stevens, JJ., dissenting).

145 Id. at 821. 
Stewart criticized the majority's reliance on the in rem precedents to support the dismissal of an in personam action. He argued that the in rem doctrine "applies only when exclusive control over the subject matter is necessary to effectuate a court's judgment," and that the determination of water rights did not require the federal court to obtain in rem or quasi in rem jurisdiction over the river. ${ }^{146}$ The dissent also found fault with the majority's factual assumptions, characterizing the majority's view that dismissal of the federal suit would avoid piecemeal litigation as "simply wrong." 147 If the federal suit were to reach judgment first, its decree easily could be incorporated into the state court's water rights tabulation. ${ }^{148}$ Federal court adjudication of the Government's claim would thus be "neither more nor less 'piecemeal"" than state court adjudication of the same claims. ${ }^{149}$ As additional factors militating in favor of the exercise of federal jurisdiction, the dissent noted that some of the issues in the suit related to federal law ${ }^{150}$ and that Indian claims were involved. ${ }^{151}$ In a separate dissent, Justice Stevens added the presence of the United States as plaintiff as a factor supporting retention of federal jurisdiction. ${ }^{152}$

Although the case presented a highly unusual example of parallel proceedings, the Court's discussion of the "principles governing the contemporaneous exercise of concurrent jurisdiction" clearly has broader implications. ${ }^{153}$ The Court pointed out that the policy considerations implicated in abstention cases differ from those relevant to cases of parallel state-federal proceedings. ${ }^{154}$ Abstention

"16 Id. at 822 . This criticism of the majority's analogy to in rem cases is well-supported by the caselaw. See, e.g., Commonwealth Trust Co. v. Bradford, 297 U.S. 613, 619 (1936).

147424 U.S. at 824.

14k Id. at 824-25.

w Id. at 825. Professor Currie finds that the dissenters "had the better of the argument" on this point. Currie, The Supreme Court and Federal Jurisdiction: 1975 Term, 1976 SuP. CT. Rev. 183, 214.

t30 424 U.S. at $825-26$.

151 The Court's traditional policy is to avoid state jurisdiction over Indians. Id.

152 Id. at 826 (Stevens, J., dissenting).

${ }^{153}$ See Calvert Fire Ins. Co. v. Will, 560 F.2d 792 (7th Cir. 1977). In Calvert the Seventh Circuit overruled Aetna State Bank v. Altheimer, 430 F.2d 750 (7th Cir. 1970), discussed in text and notes at notes 96-97 supra. The court held that "[ $t]$ he rationale developed in Aetna can no longer stand in light of the Supreme Court's decision in Colorado River." 560 F.2d at 796. Rehearing en banc was denied in Calvert, but four judges who were not members of the panel filed a statement indicating their belief that Aetna State Bank and Colorado River could be reconciled. $560 \mathrm{~F} .2 \mathrm{~d}$ at $796 \mathrm{n} .5$.

ist Several courts do not distinguish the two doctrines. See, e.g., Aetna State Bank v. Altheimer, 430 F.2d 750, 755 (7th Cir. 1970); Amdur v. Lizars, 372 F.2d 103, 106-07 (4th Cir. 1967); Universal Gypsum of Georgia, Inc. v. American Cyanamid Co., 390 F. Supp. 824, 829 (S.D.N.Y. 1975). 
rests on principles of proper constitutional adjudication and on regard for federal-state relationships, whereas federal court stays in deference to pending state court proceedings are based on a concern for "wise judicial administration." The Court concluded that while concerns of judicial efficiency alone might justify stays to avoid duplicative litigation in two federal courts, the obligation to exercise federal jurisdiction outweighs such concerns when the parallel suit is pending in a state court. The circuits that follow the pragmatic view and defer readily to the discretion of the trial court in granting stays had deemphasized this distinction and applied essentially the same criteria in reviewing stays in deference to state court proceedings as those applied to stays in deference to proceedings in another federal court. 155

Colorado River's analysis of the considerations involved in determining the existence of "exceptional circumstances" does suggest a balancing test, but the considerations differ significantly from those balanced by the circuit courts. On one side is the obligation to exercise jurisdiction, and on the other the circumstances counseling against concurrent federal proceedings. As the Court's dissenters pointed out, however, special factors that cut in favor of exercising federal jurisdiction-factors such as the involvement of Indian rights and the presence of the United States as plaintiff-should also be considered. It may be true that "there is no scale in which the balancing process called for . . . can take place"; ${ }^{156}$ Colorado River itself provides little guidance on how its balancing test is to be applied. ${ }^{157}$ Some assistance, however, can be drawn from the Supreme Court's treatment of concurrent jurisdiction problems in related contexts.

155 See text and notes at notes 104-110 supra.

${ }^{158} \mathrm{C}$. WRIGHT, supra note 48 , at 275 (criticizing the balancing test offered in Byrd v. Blue Ridge Rural Elec. Coop., Inc., 356 U.S. 525 (1958)).

${ }^{157}$ The Colorado River opinion expressly reserved opinion on even the most proximate consequences of its analysis:

We need not decide, for example, whether, despite the McCarran Amendment, dismissal would be warranted if more extensive proceedings had occurred in the District Court prior to dismissal, if the involvement of state water rights were less extensive than it is here, or if the state proceeding were in some respect inadequate to resolve the federal claims.

Whether similar considerations would permit dismissal of a water suit brought by a private party in federal district court is a question we need not now decide. 424 U.S. at $820 \&$ n.26. 


\section{Application of the Exceptional Circumstances Standard}

The Supreme Court has approved stays or dismissals amounting to a refusal to exercise federal jurisdiction in circumstances where it has discovered a strong countervailing policy embodied in a federal statute or developed by the federal courts that counterbalances the obligation to exercise jurisdiction. This development suggests a rationale for the power to decline jurisdiction, a rationale that can guide courts in the exercise of that power. The obligation to exercise jurisdiction is based on the deference due the congressional policy judgments that underlie the broadly drawn grants of jurisdiction. ${ }^{158}$ Courts will not inquire whether the policy justification underlying the grant of jurisdiction applies in the particular case. In a diversity suit, for example, a court does not ask whether the defendant in that case needs to be protected from local bias. But when a stay or dismissal would further a more particularized policy, the obligation to exercise jurisdiction may be outweighed. The obligation can also be overcome if Congress has indicated that the policy supporting the exercise of federal jurisdiction is not compelling in the particular case. Thus, the consent to suit provision involved in Colorado River arguably represented a Congressional judgment that state courts are adequate to adjudicate federal interests in water rights cases, and concomitantly that the policy underlying the grant of jurisdiction where the United States sues as plaintiff is not particularly compelling when the United States sues for a declaration of its water rights. Similarly, in Langnes $v$. Green, ${ }^{159}$ the savings clause in the grant of admiralty jurisdiction expressed a judgment that common law remedies should be preserved, and that policy judgment supported a stay of the federal action where the exercise of properly-invoked federal jurisdiction might result in the destruction of the federal defendant's common law rights.

This analysis of Colorado River, the Court's distinction between abstention and parallel jurisdiction doctrines notwithstand-

${ }^{158} 28$ U.S.C. $\$ 1332$ (1970) (diversity of citizenship). See Bank of United States v. Deveaux, 9 U.S. (5 Cranch) 61, 87 (1809) (Mashall, C.J.); Frankfurter, Distribution of Judicial Power between United States and State Courts, 13 CORNELL L.Q. 499, 520 (1928) (protection of litigants from local bias).

28 U.S.C. $\$ 1331$ (1970) (federal question). See Frankfurter, supra, at 509 (special federal interest in protecting federal rights).

28 U.S.C. $\$ 1345$ (1970) (United States as plaintiff). See F. Frankfurter \& J. Landis, The Business of the SUPREME CouRT 10 (1927) (the federal government should be able to "fashion its own judicial machinery for enforcing its claims and safeguarding its agents against the obstructions and prejudices of local authorities").

iss 282 U.S. 531 (1931), discussed at text and notes at notes 73-75 supra. 
ing, suggests that the "exceptional circumstances" language means essentially the same thing in both contexts: declining jurisdiction is justified only if it is warranted by "some recognized public policy or defined principle guiding the exercise of the jurisdiction conferred." 160 Stays should be granted only in those cases in which such a policy or principle can be positively identified. The remainder of this comment examines the implications of this analysis for the treatment of certain common situations in which stays have heretofore been thought appropriate.

\section{A. Priority of Suit}

1. Repetitive and Reactive Suits. Many courts that view stays as largely within the discretion of the trial court have considered temporal priority of suit as an important, indeed controlling, factor in determining the propriety of a stay. Under certain circumstances, priority of suit can also be considered an "exceptional circumstance" because congressional policy judgments implicit in the restrictions on the removal of causes from state to federal courts ${ }^{161}$ can be invoked to counterbalance the obligation to exercise jurisdiction. These policies become relevant when a federal suit is brought after the parallel state suit.

Repetitive federal suits arise when the plaintiff in an already commenced state suit (SP) sues the state defendant (SD) in federal court. The right to remove, however, is expressly limited to the party or parties designated as defendants in the state suit; the plaintiff could not remove even if the defendant in the state court asserts a federal defense or counterclaim. ${ }^{162}$ This limitation arguably expresses a policy determination that it is not unfair to make the plaintiff abide by his initial choice of forum. ${ }^{163}$ That policy should counterbalance the obligation to exercise jurisdiction in the subse-

${ }^{160}$ Meredith v. Winter Haven, 320 U.S. 228, 234 (1943). See text and notes at notes $49-$ 50 supra.

16! The removal statutes are 28 U.S.C. $\$ \S 1441-1451$ (1970). Section 1441(a), the general removal provision, provides:

Except as otherwise expressly provided by Act of Congress, any civil action brought in a State court of which the district courts of the United States have original jurisdiction, may be removed by the defendant or the defendants, to the district court of the United States for the district and division embracing the place where such action is pending.

162 Tennessee v. Union \& Planters' Bank, 152 U.S. 454, 461-62 (1894) (defense); Shamrock Oil \& Gas Corp. v. Sheets, 313 U.S. 100, 106-07 (1941) (counterclaim). The plaintiff cannot remove by asserting that the counterclaim is a separate and independent cause of action under $\S 1441$ (c). Lee Foods Div. v. Bucy, 105 F. Supp. 402, 404 (W.D. Mo. 1952).

${ }^{16}$ Shamrock Oil Corp. v. Sheets, 313 U.S. at 106-07 n.2 (quoting H.R. REP. No. 1078, 49th Cong., 1st Sess. (1886)). 
quent repetitive federal suit.

Reactive federal suits arise when SD sues SP in federal court on a claim that either arises out of, or is intimately related to, the same transaction or occurrence that is the subject of SP's state suit, or seeks a declaration that he is not liable on SP's claim. If the prior state suit is removable, the interests of judicial economy dictate that the federal suit should be stayed or dismissed, forcing SD to employ the removal procedure. ${ }^{164}$ Because access to the federal court is not foreclosed, this result does not necessarily involve an abdication of the duty to exercise jurisdiction. ${ }^{165}$ Although the state defendant is entitled to a federal forum, the avoidance of duplicative litigation justifies declining the exercise of concurrent jurisdiction, thus forcing the state defendant to use the more efficient and convenient method of removal. ${ }^{166}$

If SP's claim is not removable and SD brings an action within the original jurisdiction of the federal court, the propriety of a stay depends on whether there is an articulable policy behind the unavailability of removal that indicates that the general policy underlying the jurisdictional basis invoked by SD is not especially important in the particular case. Where SD simply wishes to litigate the validity of SP's claim in a federal forum and, removal being unavailable, brings an action for declaratory or injunctive relief to that effect, ${ }^{167}$ it is not particularly difficult to identify a policy judgment in the restrictions on removal that might counterbalance the obligation to exercise jurisdiction.

An examination of three typical situations in which the state suit is not removable but in which SD could bring a subsequent

i4 See Yale Note, supra note 92, at 988.

${ }^{165}$ See Columbia Note, supra note 104, at 704. This analysis is similar to that used to justify the application of forum non conveniens, see Gulf Oil Corp. v. Gilbert, 330 U.S. 501 (1947), discussed at text and notes at notes 38-47 supra, and the discretionary power of the Supreme Court to decline to hear cases brought within its original jurisdiction. See note 89 supra.

I66 If the defendant failed to employ the removal procedures and removal becomes timebarred or waived, a stay would be warranted to prevent circumvention of the statutory restrictions on removal. See Columbia Note, supra note 104, at 704.

167 See, e.g., PPG Industries, Inc. v. Continental Oil Co., 478 F.2d 674 (5th Cir. 1973), discussed at text and notes at notes 114-121 supra. If only declaratory relief is sought, Brillhart v. Excess Ins. Co., 316 U.S. 491 (1942), discussed at text and notes at notes 76-79 supra, grants the federal court broad discretionary authority to decline jurisdiction. A request for injunctive relief takes the case out of the Brillhart rule if the injunction sought is not merely incidental to the declaratory relief sought. The grant of equity jurisdiction was not motivated by the convenience and expediency considerations that led to the adoption of the declaratory action, considerations that justify declining jurisdiction when it would be inconvenient to assume it. See note 120 supra. 
federal suit will illustrate the analysis. ${ }^{168}$ First, SD cannot remove a claim brought against him by SP even though he has a defense based on federal law. ${ }^{169}$ This rule reflects a policy that the state forum is adequate to adjudicate a state-based claim and any asserted defenses. ${ }^{170}$ Second, if SP's claim against SD satisfies the requirements for diversity jurisdiction, $\mathrm{SD}$ cannot remove if he is a resident of the state in which the state suit was brought. ${ }^{171}$ The congressional judgment behind the unavailability of removal in this circumstance is that the defendant does not need the protection from local bias that the diversity jurisdiction provides. ${ }^{172}$ Third, if SP's claim involves more than $\$ 10,000$, and SP and SD are diverse, removal is unavailable if the state suit involves other defendants not diverse to SP, and SP's claim against SD is not separable and independent. ${ }^{173}$ Nonremovability in this context expresses a judgment that SD does not require protection from possible local bias because the possiblity of bias is minimal when the parties aligned on one side of a state suit include among their members a nondiverse party. ${ }^{174}$ In all these situations the same policy that justifies nonremovability-the judgment that the state forum is adequate-can also counterbalance the obligation to exercise jurisdiction in a reactive federal suit brought by SD seeking to adjudicate SP's claim in a federal forum. ${ }^{175}$

1es The list is not exhaustive. For example, another limitation on removal that would support a stay is that which holds that when the action sought to be removed is premised on diversity jurisdiction, diversity must exist at the time of the petition for removal and at the time of the filing of the original complaint. See Gibson v. Bruce, 108 U.S. 561 (1883). This requirement is imposed to prevent the defendant from changing his domicile after the state action is filed in order to create diversity for removal purposes. If the defendant acquires a new domicile and then brings a reactive suit, the policy behind the nonavailability of removal counterbalances the obligation to exercise jurisdiction.

${ }_{189}$ Great Northern Ry. v. Alexander, 246 U.S. 276, 281 (1918); Bailey v. Logan Square Typographers, Inc., 441 F.2d 47, 51-52 (7th Cir. 1971).

${ }_{170}$ See Wechsler, Federal Jurisdiction and the Revision of the Judicial Code, 13 Law \& Contemp. Prob. 216, 234 (1948) ("there is no need for the original jurisdiction when litigants rely on federal rights to furnish them a shield but not a sword").

17128 U.S.C. $\$ 1441$ (b) (1970).

172 American Law Institute, Study of the Division of JuRisdiction betweEn State and FEDERAL CoURTS $\$ 1302$ (a), at 124 (1969) (commentary).

${ }^{173}$ Separable and independent claim removal is governed by 28 U.S.C. $\$ 1441$ (c) (1970). See American Fire \& Cas. Co. v. Finn, 341 U.S. 6, 14 (1951) (a claim or cause of action is not "separable or independent" from another claim "where there is a single wrong to plaintiff, for which relief is sought, arising from an interlocked series of transactions").

${ }^{17}$ A similar policy judgment underlies the Strawbridge rule requiring complete diversity in original jurisdiction cases. Strawbridge v. Curtiss, 7 U.S. (3 Cranch) 267 (1806). See Currie, The Federal Courts and the American Law Institute (pt. I), 36 U. ChI. L. REv. 1, 22 (1968).

${ }^{173}$ Cf. National Cancer Hosp. of America v. Webster, 251 F.2d 466, 468 (2d Cir. 1958) (L. Hand, J.), cert. denied, 361 U.S. 824 (1959) ("An action under [the Declaratory Judgment 
The identification of policies in the limitations on removal that can counterbalance the obligation to exercise jurisdiction is more problematic in the case in which SD's federal suit asserts an affirmative claim for relief on a cause of action arising out of the same transaction or occurrence that is the subject of SP's nonremovable claim in state court. A defendant cannot remove a state suit on the ground that he possesses a federally cognizable counterclaim. ${ }^{176}$ However, if SD brings a federal action, the rules of claim and issue preclusion will operate so that a judgment in either the state suit (SP v. SD) or the subsequently-commenced federal suit (SD v. SP) will, for all practical purposes, conclude the proceedings in the other forum. ${ }^{177}$ If the state proceeding reaches judgment prior to the

Act] is not the equivalent of a removal, and must satisfy the conditions imposed upon such actions").

In suits for a declaratory judgment federal jurisdiction is determined as if the suit were a coercive one. See Skelly Oil Co. v. Phillips Petroleum Co., 339 U.S. 667, 673-74 (1950); Allegheny Airlines, Inc. v. Pennsylvania Public Util. Comm'n, 465 F.2d 237, 241 (3d Cir. 1972), cert. denied, 410 U.S. 943 (1973). The federal courts therefore would not normally have jurisdiction over SD's reactive suit if SD asserts a federal defense as the basis for nonliability on SP's claim, SP's claim is based on state law, and SP and SD are not diverse. Even when these circumstances are met, SD might yet be able to frame his claim to state a federal cause of action, as in a civil rights suit seeking to restrain state civil proceedings. See text and notes at notes 61-68 supra. One commentator's analysis of the effect of Colorado River in federal civil rights cases concludes that the policy behind nonremovability on the basis of a federal defense is "at least as strong" as the policy discerned in the McCarran Amendment in Colorado River, thus warranting dismissal of a federal civil rights suit if the state proceeding sought to be restrained was filed first. See Bartels, supra note 62, at 80-81. See also D. CuRRIE, Federal JURISDiction in a Nutshell 180-81 (1976).

i76 This is presumably because the original action is not cognizable in the federal courts. See Currie, supra note 2 , at $274 \& \mathrm{n} .263$. The rule hás been much criticized, see, e.g., AMERICAN LAW INSTTTUTE, supra note 172, \$\$1312(a)(3), 1304(d), and proposals for amending the Judicial Code to provide for removal have been introduced in Congress. Federal Court Jurisdiction Act of 1971, S. 1876, 92d Cong., 1st Sess., 117 Cong. REc. 15088-96 (1971).

Several courts hold that the counterclaim may be considered in determining the amount in controversy in the state case. For example, if the plaintiff sues a diverse defendant in state court, claiming less than $\$ 10,000$ damages, and the defendant counterclaims for more than $\$ 10,000$, the defendant would have the right to remove since the amount in controversy exceeds $\$ 10,000$. See, e.g., National Upholstery Co. v. Corley, 144 F. Supp. 658 (M.D.N.C. 1956); Lange v. Chicago, R.I. \& P.R.R., 99 F. Supp. 1 (D. Iowa 1951). Professor Wright thinks that it is "perfectly consistent with the statute to hold that a claim that arises from the transaction sued on and that, by the relevant state law, must either be asserted in the action or forever barred, is in controversy." C. WRIGHT, supra note 48 , at 144 . The majority of courts reject this analysis. See, e.g., Cabe v. Pennwalt Corp., 372 F. Supp. 780 (W.D.N.C. 1974); West Virginia State Bar v. Bostic, 351 F. Supp. 1118 (S.D.W. Va. 1972). Professor Moore supports this position, relying on the intent of Congress to limit removal jurisdiction and the argument that federal removal practice should not be dependent on state procedural rules determining the status of a counterclaim as permissive or compulsory. 1A MOORE's FEDERAL Practice $\Uparrow$ 0.167[8], at 409 (2d ed. 1974).

${ }^{177}$ Claim preclusion would conclude the federal proceedings were the state suit to reach judgment first, as the claim asserted in federal court would be a compulsory counterclaim in 
federal suit, the federal proceeding will have been utterly wasteful; if the federal suit reaches judgment first, SD may accomplish the effect of removal-federal adjudication of the controversy-even though removal itself is not available. To ascribe a policy judgment to the nonavailability of removal in this situation, however, would be to say that the policy justifications underlying the grants of jurisdiction are in some mysterious way diminished simply because the events forming the basis of the federally cognizable claim also give rise to a state cause of action and the state claim happened to be filed first. The only possible justification for the rule that a defendant cannot remove on the basis of a counterclaim is to prevent the abuse of filing a barely colorable counterclaim in state court in order to effect removal. This justification is essentially unrelated to the importance of exercising of federal jurisdiction in most cases, and the unavailability of removal in this situation therefore has little or no relevance to the propriety of a stay. ${ }^{178}$

Nevertheless, there will be cases where the policy underlying the nonremovability of SP's claim is applicable despite SD's assertion of an affirmative cause of action in federal court. For example, if removal on the basis of diversity of citizenship is not available because $\mathrm{SD}$ is a resident of the state in which the state suit was brought, and hence does not in theory need protection from local bias, the policy judgment underlying the restriction on removal should usually warrant staying a subsequently commenced federal suit and thus effectively requiring SD to submit his counterclaim for adjudication in the state court. ${ }^{179}$

the state suit. See note 1 supra. A judgment first on the federal claim would not necessarily conclude the state proceedings. SP would not be required to assert his claim against SD in the federal suit under FED. R. Civ. P. 13(a), which provides that a counterclaim is not compulsory if "at the time the action was commenced the claim was the subject of another pending action." It is likely, however, that SP would assert his claim, if only to protect himself. See Feinberg, Establishing Jurisdictional Amount by a Counterclaim, 21 Mo. L. Rev. 243,250 (1956). Moreover, if the same facts constitute both a ground for defense in the state suit and for the counterclaim, issue preclusion would apply to conclude the state litigation. For example, in City of Ironton v. Harrison Constr. Co., 212 F. 353 (6th Cir. 1914), the city sued the construction company for breach of contract in state court, and the company then sued the city in federal court alleging breach of the same contract. The federal judgment would conclude the state suit whether or not the city asserted its counterclaim in the subsequent federal action.

178 The Congressional design thus actually encourages duplicative litigation by creating a class of cases in which neither party to a state suit can remove but one of the litigants is entitled to bring an original action in federal court and gamble on winning a race to judgment. Whichever court wins the race will effectively decide the controversy-hardly a reasonable or principled way to effect the division of responsibility between the federal and state courts. The proper solution would appear to be an amendment to the removal statutes. See note 176 supra.

179 See Universal Gypsum of Georgia, Inc. v. American Cyanamid Co., 390 F. Supp. 824 
In sum, the above analysis suggests that in determining the propriety of a stay in a repetitive or reactive federal suit instituted subsequent to a state suit involving the same issues and parties, the federal court should first determine if the state suit is removable. If it is, a stay should be granted. If it is not, the court should then determine why removal is unavailable. If nonremovability can be said to express a policy judgment that the state forum is adequate to decide the controversy, and therefore that the policies underlying the jurisdictional grant invoked by the federal plaintiff are not very strong in the particular case, then the federal action should ordinarily be stayed. ${ }^{180}$

2. Class Actions and Derivative Suits. Another type of duplicative federal suit arises when a federal plaintiff class action in-

(S.D.N.Y. 1975). In Universal Gypsum the parallel actions involved the construction of the same contract. Cyanamid's New York state court action was initially removed to federal district court, but remanded to state court upon a finding that Gypsum was a citizen of New York under the diversity statute. The federal court stayed Gypsum's reactive suit, articulating the rule that

when a federal diversity action raising only state law issues has been commenced at a time when a previously or simultaneously commenced action is pending in the courts of his own state, involving the same parties and issues, the district court, absent some persuasive reason for contrary action, should stay the proceedings before it until the state court has had the opportunity to pass upon the claim.

390 F. Supp. at 830 . Although the court in Gypsum did not remark upon the policies implicit in the limitations on removal it did note that "Gypsum's invocation of diversity jurisdiction is without support in the primary purposes and theoretical basis of that grant of adjudicatory authority." Id. at 828.

iso Application of the Erie doctrine may require dismissal of a subsequent federal action under certain circumstances. See generally Columbia Note, supra note 104, at 693-98, discussing cases in which an action is brought in federal court in a state whose courts would stay or dismiss the suit in deference to a pending action in the same or a different state. Byrd v. Blue Ridge Rural Elec. Coop., Inc., 356 U.S. 525 (1958), requires a court to balance the policies behind the conflicting federal and state rules in making the Erie decision. Concluding that the state policy behind a rule mandating a stay or dismissal is primarily one of conserving state judicial resources, the Note argues that Erie does not require the federal court to apply the state rule. The federal policy underlying the provision of a federal forum more than outweighs the state policy.

When the state rule mandating dismissal of the subsequent suit has a purpose other than the efficient management of litigation in the state courts, the Erie question becomes more problematic. In Arny v. Philadelphia Transp. Co., 163 F. Supp. 953 (E.D. Pa. 1958), appeal dismissed, 266 F.2d 869 (3d Cir. 1959), the district court ordered a stay in a wrongful death action in deference to pending death and survival actions in state court because Pennsylvania law required wrongful death and survival actions to be consolidated. The alleged purpose of the state rule was to avoid overlapping remedies, and the court labeled the defendant's right to protection against double recovery a "substantive" right. Id. at 955 . That analysis, however, had been previously considered and rejected by a different district court, see Krivan v. Hourican, 117 F. Supp. 908 (W.D. Pa. 1954), and has been criticized by commentators. See Columbia Note, supra note 104, at 692 n.57. The Krivan court noted that proper jury instructions would adequately protect the defendant. Under this view, the only substantial purpose of the state rule is judicial convenience, and Erie does not require dismissal. 
volves substantially the same class, defendants, and issues as a previously commenced class suit in state court. When the named plaintiff $\mathrm{s}^{181}$ or motivating forces ${ }^{182}$ in the two suits are the same, the policy underlying the rule that plaintiffs cannot remove-a judgment that it is not unfair to restrict the plaintiff to his initial choice of forum-argues for a stay of the action. ${ }^{183}$ When the federal and state suits are brought by different plaintiffs, however, the federal plaintiff did not make the initial choice of forum. An explanation of the provisions governing class actions ${ }^{184}$ and stockholder derivative suits ${ }^{185}$ indicates that under certain circumstances a stay is nevertheless appropriate.

A court has some discretion over the maintenance of certain class actions. To certify a "common question" class action under rule $23(b)(3)$, a court must find that "a class action is superior to other available methods for the fair and efficient adjudication of the controversy." 186 One of the four factors listed as pertinent to that determination is "the extent and nature of any litigation concerning the controversy already commenced by or against members of the class." ${ }^{187}$ Several courts have invoked this factor in refusing to certify a class action when other related class suits are pending. ${ }^{188}$ The common question class action can be viewed as a device for achieving comprehensive and efficient adjudication of related claims. ${ }^{189} \mathrm{~A}$ duplicative class action undercuts the economies that would otherwise be realized, and is typically unnecessary to avoid the inefficiencies of individual litigation. ${ }^{190}$

That substantial attorneys' fees are awarded those who successfully prosecute certain class actions and derivative suits also sup-

เsı See, e.g., Rosenfeld v. Black, 445 F.2d 1337, 1341 (2d Cir. 1971).

${ }^{182}$ See, e.g., Mottolese v. Kaufman, 176 F.2d 301, 301-02 (2d Cir. 1949); Georgia Ass'n of Educators v. Harris, 403 F. Supp. 961, 963-64 (N.D. Ga. 1975) (same attorneys, although different named plaintiffs).

${ }_{183}$ See text and notes at notes 162-163 supra.

tst Fed. R. Civ. P. 23.

iss Id. 23.1.

${ }^{185}$ Id. $23(\mathrm{~b})(3)$.

${ }_{187} I d .23(\mathrm{~b})(3)(\mathrm{B})$.

188 Mitchell v. Texas Gulf Sulphur Co., 446 F.2d 90, 107 (10th Cir. 1971); Barkel v. Chas. Pfizer \& Co., 51 F.R.D. 504, 505 (S.D.N.Y. 1970).

${ }_{189}$ See Developments in the Law-Class Actions, 89 HARv. L. Rev. 1318, 1341-42 (1976); Advisory Committee's Note, 1966 Amendments, FED. R. Crv. P. 23(b)(3) ("Subdivision (b)(3) encompasses those cases in which a class action would achieve economies of time, effort, and expense, and promote uniformity of decision as to persons similarly situated, without sacrificing procedural fairness or bringing about other undesirable results.").

190 A refusal to allow the action is therefore justified by the policies of Rule 23. This analysis is similar to that used to justify stays when federal jurisdiction is invoked pursuant to the Declaratory Judgment Act. See text and notes at notes 76-79 supra. 
ports the exercise of the power to stay. ${ }^{191}$ The award of attorneys' fees reflects a public policy in favor of such suits as a means to redress small claims and, in the case of derivative actions, to control corporate management. ${ }^{192}$ If a subsequently filed federal class action or derivative suit is not stayed, however, the plaintiff who filed first could lose such fees if the federal court reaches judgment first. This situation presents great possibilities for unfairness, since the first plaintiff may have incurred substantial expenses, ${ }^{193}$ and the second plaintiff may have simply plagiarized the first plaintiff's complaint. ${ }^{194}$ A final characteristic of class and derivative actions, the high incidence of strike suits, ${ }^{195}$ also argues in favor of the power to stay. ${ }^{196}$ The availability of two forums in which to litigate a class action or derivative suit unnecessarily increases the nuisance value of threatened litigation.

These considerations-the efficiency justification for class action treatment and the heightened possibilities of unfairness in multiple class proceedings-invite a finding of exceptional circumstances within the Colorado River standard. Such a finding should be conditioned on a determination that the federal plaintiffs are adequately represented in the state suit ${ }^{197}$ and that the state suit is proceeding normally. ${ }^{198}$

When an individual federal court action is predicated on a claim that is also the subject of a class action already pending in state court, the general priority rule is subject to qualification. If the

191 See Yale Note, supra note 92 , at 989-90.

192 See generally Developments in the Law-Class Actions, 89 HARv. L. REv. 1318, 1611 (1976); Dykstra, The Revival of the Derivative Suit, 116 U. PA. L. REv. 74, 77-82 (1967).

${ }^{193}$ The expense may be especially high if the plaintiff is required to pay the cost of notice to all members of the class. See, e.g., Eisen v. Carlisle \& Jacquelin, 417 .U.S. 156, 173-77 (1974).

194 See Yale Note, supra note 92 , at 989 n.48.

195 See Dykstra, The Revival of the Derivative Suit, 116 U. PA. L. Rev. 74, 75 (1967).

${ }^{196}$ In Amdur v. Lizars, 372 F.2d 103, 107 (4th Cir. 1967), the court noted that stays in stockholder derivative suits were especially justifiable because of the "inconvenience, loss of time, and expense inflicted upon the corporate defendant, and the danger that its treasury may be depleted by litigation supposedly prosecuted for its benefit." See also Rosenfeld v. Black, 445 F.2d 1337, 1341 n.5 (2d Cir. 1971).

${ }^{197}$ If the federal plaintiff has the right to intervene and participate in the state suit, the concern regarding adequate representation in the state action is less important. See Weiss v. Doyle, 178 F. Supp. 566, 568-70 (S.D.N.Y. 1959); Columbia Note, supra note 104, at 709.

${ }^{19 x}$ The possibility of collusion between the class plaintiffs and the defendant in the state suit cannot be disregarded. See Yale Note, supra note 92, at 985 . The federal class action rule provides for court supervision of settlements. FED. R. Civ. P. 23(e). If the state class action rule governing the parallel action contains no comparable provision, and the federal plaintiff makes a colorable showing of possible collusion, the federal action should be allowed to proceed. 
federal plaintiff opts out of the state class action under the state's rule, a stay should not be granted. ${ }^{199}$ If he does not opt out, he has in effect chosen the state forum, and a stay of the federal action is warranted. However, if the state class action rule does not permit the class members to opt out, the federal plaintiff's individual suit should ordinarily be allowed to proceed. Because the federal plaintiff has not chosen the state forum, the policy analysis of the removal statutes and the special considerations regarding class action or derivative suits do not apply.

\section{B. The Avoidance of Piecemeal Litigation}

In Colorado River, the Supreme Court included the avoidance of piecemeal litigation as a consideration relevant to determining the propriety of a stay. ${ }^{200}$ The policy against piecemeal litigation has been given significant weight in the development of the doctrines of ancillary and pendent jurisdiction. ${ }^{201}$ These doctrines empower a federal court, in the interests of "judicial economy, convenience, and fairness to litigants," 202 to assume jurisdiction over claims that do not independently satisfy the jurisdictional requirements. When these interests are advanced to justify declining federal jurisdiction rather than to justify exercising it, however, Colorado River's implication that concerns about judicial economy cannot overcome the

199 See, e.g., FED. R. Civ. P. 23(c)(2), providing that the notice required in (b)(3) class actions "shall advise each member that . . . the court will exclude him from the class if he so requests by a specified date."

If the plaintiff has opted out, he may not take advantage of the class judgment through issue preclusion, even in those jurisdictions that have abandoned the mutuality requirement. See, e.g., C. WRIGHT, supra note 48, at 354; Kaplan, Continuing Work of the Civil Committee: 1966 Amendments of the Federal Rules of Civil Procedure I, 81 HARv. L. Rev. 356, 391 n.136 (1967). Once the federal plaintiff opts out of the state class action, his individual suit and the state class action are no longer true parallel suits. See note 1 supra.

200424 U.S. at 818. See also Thompson v. Boyle, 417 F.2d 1041 (5th Cir. 1969) (federal suit's lack of comprehensiveness is a "compelling reason" for a stay), cert. denied, 397 U.S. 972 (1970); Reiter v. Universal Marian Corp., 173 F. Supp. 13, 15 (D.D.C. 1959), vacated as moot, 273 F.2d 820 (D.C. Cir. 1960).

201 The doctrine of ancillary jurisdiction allows the federal court to assume jurisdiction over a case in its entirety and to decide matters that are incidental to the disposition of the issue properly before it even if the ancillary matters do not independently satisfy the jurisdictional requirements. See Revere Copper \& Brass, Inc. v. Aetna Cas. \& Sur. Co., 426 F.2d 708, 712-13 (5th Cir. 1970); C. Wright, supra note 48, at 21-24; Goldberg, The Influence of Procedural Rules on Federal Jurisdiction, 28 STAN. L. Rev. 395, 415-31 (1976).

Pendent jurisdiction permits state claims to be joined in federal suits that concern closely related federal claims. See United Mine Workers v. Gibbs, 383 U.S. 715, 725 (1966) (pendent jurisdiction established when the federal and state claims "derive from a common nucleus of operative fact"); C. WRIGHT, supra note 48, at 72-77.

202 United Mine Workers v. Gibbs, 383 U.S. 715, 726 (1966). 
obligation to exercise jurisdiction ${ }^{203}$ seems applicable. The greater comprehensiveness of the parallel state suit therefore should not itself constitute an exceptional circumstance. Indeed, application of the doctrines of pendent and ancillary jusrisdiction could in some cases broaden the scope of the federal suit so that the federal court would be an equally efficient forum. ${ }^{204}$

Although the probability of piecemeal litigation cannot constitute an exceptional circumstance, it will sometimes work in tandem with the removal policies to support a stay. For example, when the prior state suit involves state claims between parties who are not completely diverse and one of the diverse defendants brings a reactive federal suit less comprehensive than the state suit, ${ }^{205}$ both the removal policy and piecemeal litigation policy would strongly counsel a finding of exceptional circumstances sufficient to warrant staying the federal suit.

On the other hand, the two policies will sometimes conflict. When a plaintiff's federal action is more comprehensive than a prior nonremovable state suit in which he is named as a defendant, the desire to avoid piecemeal litigation might lead the federal court to deny a stay even if the nonremovability of the state suit represents a policy judgment supporting declining jurisdiction. If the factual issues common to both suits are separable from many of the issues that are before the federal court only, a stay of the federal proceedings could be limited to the common issues. ${ }^{208}$ The difficulty arises in cases where the factual inquiries are intertwined. In such a situation, the policy against piecemeal litigation points toward denying the stay: to stay the federal suit would be to decline jurisdiction in

${ }^{203}$ See text and notes at notes 134-136, 153-155 supra.

204 See, e.g., Chintala v. Diamond Reo Trucks, Inc., 393 F. Supp. 1392 (E.D. Pa. 1975). Chintala brought a diversity suit in federal court seeking damages against Diamond Reo under the Pennsylvania wrongful death and survival statutes. Two weeks later Chintala commenced an action in Pennsylvania state court for similar relief, but named a different defendant. The state defendant brought in four other defendants, including Diamond Reo. Diamond Reo threatened to bring in the four other state defendants as third-party defendants in the federal action. Although ancillary jurisdiction attaches to cross-claims and the federal suit could have been broadened, the district court stayed the federal suit on the ground that the state proceedings were more comprehensive than the federal suit.

Jurisdictional requirements such as complete diversity will often make pendent and ancillary jurisdiction unavailable to cure the federal suit's lack of comprehensiveness. See, e.g., Thompson v. Boyle, 417 F.2d 1041 (5th Cir. 1969). See also Bethlehem Steel Corp. v. Tishman Realty \& Constr. Co., 72 F.R.D. 33, 36 (S.D.N.Y. 1976) (federal court in New York could not obtain personal jurisdiction of parties over whom the Califormia state court had already assumed jurisdiction).

${ }^{205}$ See, e.g., PPG Indus., Inc. v. Continental Oil Co., 478 F.2d 674 (5th Cir. 1973).

${ }_{206}$ See, e.g., Lane v. Hills, 72 F.R.D. 158, 160 (D.N.J. 1976); United States v. Finn, 127 F. Supp. 158, 160 (S.D. Cal. 1954), modified, 239 F.2d 679 (9th Cir. 1956). 
favor of a less comprehensive suit, thus ensuring a piecemeal resolution of the controversy. The possibility of piecemeal litigation will remain, however, even if the stay is denied, since the state suit could reach judgment before the federal suit-a likely result in view of the priority of the state suit and the greater comprehensiveness of the federal proceedings.

This conflict can be resolved by viewing the propriety of. a stay as dependent on the degree to which the federal proceeding is more comprehensive than the parallel state action. If it is significantly more comprehensive, the presumption underlying the nonremovability of the state suit-the adequacy of the state forum-is rebutted, and the motion for a stay should be denied. ${ }^{207}$ Moreover, the presence of additional parties and issues before the federal court lessens the likelihood of unnecessary duplication of effort. Since parties not before the state court will not be bound by the state court judgment, relitigation of the factual issues in federal court is inevitable and cannot be avoided by a stay. In addition, duplication of effort may be avoided altogether since the state court might stay the proceedings before it in deference to the more comprehensive federal suit. ${ }^{208}$

\section{The Relative Convenience of the Federal Forum}

Another factor listed in the Colorado River opinion as relevant to the appropriateness of a stay or dismissal is "the inconvenience of the federal forum." ${ }^{209}$ If the federal forum is an inconvenient location for the litigation, the less drastic remedy of transfer ${ }^{210}$ will typically cure the inconvenience. But when the federal court is substantially more convenient than the state forum, policies favoring a stay of the federal action may be overridden. Because the adequacy of the state forum is doubtful, the stay should not be granted. Furthermore, the state court might decide to invoke the doctrine of forum non conveniens and dismiss the suit before it. ${ }^{211}$

${ }^{207}$ See, e.g., Ferguson v. Tabah, 288 F.2d 665, 672 (2d Cir. 1961); Kahan v. Rosenstiel, 285 F. Supp. 61 (D. Del. 1968); Levy v. Alexander, 170 F. Supp. 439 (S.D.N.Y. 1959).

${ }_{20 \times}$ See, e.g., Moeckel v. Delaware Engineering \& Design Corp., 366 A.2d 507 (Del. 1976). See text and notes at notes 21-24 supra.

${ }^{209} 424$ U.S. at 818.

210 28 U.S.C. \$ 1404(a) (1970). The Court in Colorado River notes the geographic distance between the district court and the court in Division 7 as one of the "significant" factors supporting dismissal. 424 U.S. at 820 . As the dissenters point out, however, the district court was authorized to sit in Durango, the headquarters of Division 7. Id. at 823-24 n.6. The convenience factors should weigh heavily in favor of a stay or dismissal only in cases in which no available federal forum is convenient. See text at note 47 supra.

211 See, e.g., American Fidelity Fire Ins. Co. v. Construcciones Werl, Inc., 70 F.R.D. 695 


\section{Miscellaneous Factors}

It is impossible to construct an exhaustive list of the factors that might be pertinent to determining whether exceptional circumstances exist-a discussion of the issue prior to Colorado River would have been unlikely to spot the relevance of the McCarran Amendment. Another example of a unique policy operative in a small number of cases is provided by the case of Scott $v$. Germano. ${ }^{212}$ The Germano case will serve to suggest the variety of considerations potentially involved.

In Germano, the Supreme Court ordered the district court to vacate its orders invalidating the apportionment of the Illinois Senate. The orders required the defendants to submit any proposed implementation or amendment of the apportionment laws to the court for approval and, if they submitted no such changes, to show cause why the senators should not be elected on an at-large basis. The Court also directed the district court to stay the proceedings before it in deference to an Illinois Supreme Court ruling invalidating the apportionment. Although the district court had plenary jurisdiction, the Court held that the policy of encouraging "appropriate action by the States" in apportionment cases dictated that the district court refrain from further exercise of that jurisdiction. ${ }^{213}$ Although both the federal and state courts had reached judgment in Germano, the policy favoring deference to state court proceedings that the Court relied upon would seem equally pertinent to the stay issue in cases of concurrent state and federal apportionment challenges. That policy consideration would arguably warrant staying the federal suit.

Even when a policy counterbalancing the obligation to exercise jurisdiction can be identified, whether it be a policy underlying the removal statutes or a more particularized policy like those in Colorado River or Germano, other factors might favor the exercise of jurisdiction. The implicit categorical assumption that the state forum is adequate may be rebutted in individual cases by, among

(D.V.I. 1976), a reactive suit filed in the District of the Virgin Islands. Despite the pendency of a prior suit filed in a Puerto Rican court, the district judge refused to stay the federal action because the events giving rise to the litigation centered in the Virgin Islands, Virgin Island law would apply under choice of law rules, and other, related lawsuits were pending before him. He concluded, "I find it hard to believe that judicial economy and litigants' interests would not better be served by the Puerto Rican court staying its own proceedings." Id. at 698. See Lansverk v. Studebaker-Packard Corp., 54 Wash. 2d 124, 134-35, 338 P.2d 747, 75253 (1959) (collecting state forum non conveniens cases).

212381 U.S. 407 (1965).

${ }^{213}$ Id. at 409. 
other factors, the exclusiveness of federal jurisdiction, the prejudice likely to result from the absence of federal procedure, or the existence of circumstances justifying the duplicative suit. ${ }^{214}$ When federal jurisdiction is based on an exclusive grant, such as those in the Securities Act of $1934^{215}$ or the Clayton Act, ${ }^{216}$ the desire for uniform and effective administration of the federal statute should lead courts to resist stay motions even though other factors favoring a stay are present. ${ }^{217}$ Federal courts should also consider the proce-

211 Several courts have considered the res judicata effect a nonjury state determination would have on a federal litigant's right to jury trial. See, e.g., Lecor, Inc. v. United States Dist. Ct., 502 F.2d 104 (9th Cir. 1974); Mach-Tronics, Inc. v. Zirpoli, 316 F.2d 820, 832-33 (9th Cir. 1963). See Vestal, Reactive Litigation, 47 Iowa L. Rev. 11, 26-27 (1961). The seventh amendment right to jury trial has not been extended to the states through the fourteenth amendment. See Curtis v. Loether, 415 U.S. 189, 192 n.6 (1974).

Rachal v. Hill, 435 F.2d 59 (5th Cir. 1970), cert. denied, 403 U.S. 904 (1971), suggests that principles of collateral estoppel would not apply if the state court reached judgment prior to the federal suit. The court held that a party could not lose his constitutional right to jury trial through application of collateral estoppel based on a prior injunctive action brought by the SEC, an equitable, nonjury proceeding. Rachal has been heavily criticized, however. See Crane Co. v. American Standard, Inc., 490 F.2d 332, 343 n.15 (2d Cir. 1973) (dictum) (Friendly, J.); Shapiro \& Coquillette, The Fetish of Jury Trial in Civil Cases: A Comment on Rachal v. Hill, 85 HARv. L. REv. 442 (1971); Comment, The Use of Government Judgments in Private Antitrust Litigation: Clayton Act Section 5(a), Collateral Estoppel, and Jury Trial, 43 U. CHI. L. REv. 338, 369-71 (1976). The Second Circuit implicitly rejected Rachal in Goldman, Sachs \& Co. v. Edelstein, 494 F.2d 76 (2d Cir. 1974).

Even if the seventh amendment does not require the denial of the stay, an affirmative federal policy favoring jury trial should be sufficient to warrant exercising federal jurisdiction. Whether such a policy exists independent of the seventh amendment is not yet settled. Compare Curtis v. Loether, 415 U.S. 189, 198 (1974) (acknowledging that policy considerations may call for curtailment of the right to a jury trial) with Byrd v. Blue Ridge Rural Elec. Coop., Inc., 356 U.S. 525, 537-39 (1958).

${ }_{215} 15$ U.S.C. $\$ 78 \mathrm{aa}(1970)$.

21615 U.S.C. $\$ 15$ (1970).

${ }^{217}$ See Calvert Fire Ins. Co. v. Will, 560 F.2d 792 (7th Cir. 1977); Cotler v. Inter-County Orthopaedic Ass'n, P.A., 526 F.2d 537 (3d Cir. 1975); McGough v. First Arlington Nat'l Bank, 519 F.2d 552 (7th Cir. 1975); Columbia Note, supra note 104, at 700. Some courts have even held that the judgment of a state court may not be given res judicata effect in a suit brought under the exclusive jurisdiction of the federal courts. See, e.g., Lyons v. Westinghouse Elec. Corp., 222 F.2d 184, 189 (2d Cir.), cert. denied, 350 U.S. 825 (1955). The modern trend is to reject that holding. See, e.g., Granader v. Public Bank, 417 F.2d 75, 81 (6th Cir. 1969), cert. denied, 397 U.S. 1065 (1970); Vanderveer v. Erie Malleable Iron Co., 238 F.2d 510, 512-13 (3d Cir. 1956), cert. denied, 353 U.S. 937 (1957). See generally Note, Res Judicata: Exclusive Federal Jurisdiction and the Effect of Prior State Court Determinations, 53 VA. L. REv. 1360 (1967).

Section 1345 jurisdiction, governing civil claims brought by the United States, is another situation in which federal jurisdiction should rarely be relinquished. See United States v. Public Serv. Comm'n, 422 F. Supp. 676, 679 (D. Md. 1976). The Anti-Injunction Statute, 28 U.S.C. \$2283 (1970), does not apply to injunctions sought by the United States. Leiter Minerals, Inc. v: United States, 352 U.S. 220, 224-25 (1957). The considerations that prompted this construction - that the federal government should be able to "fashion its own judicial machinery for enforcing its claims and safeguarding its agents against the obstruc- 
dural advantages available to litigants in the federal forum. ${ }^{218}$ Several courts have conditioned stays on the use of federal discovery in the state suit; ${ }^{219}$ commentators have justifiably criticized the practice. ${ }^{220}$ If the deprivation of federal procedure will severely disadvantage the federal plaintiff, the court should refuse a stay regardless of other factors counterbalancing the obligation to exercise jurisdiction. ${ }^{221}$ Finally, duplicative litigation may be justified in some instances. ${ }^{222}$ For example, a reactive suit may be justified if the state plaintiff acted in bad faith in bringing suit in state court. ${ }^{223}$

\section{Conclusion}

This comment has argued that the "exceptional circumstances" standard announced by the Supreme Court in Colorado River for determining the propriety of stays and dismissals in deference to parallel state court proceedings is consistent with the Court's prior decisions on related jurisdictional problems. Before Colorado River, a number of lower federal courts adopted a broad discretionary standard relating to stays, relying on practical considerations, ${ }^{224}$ an expansive reading of Supreme Court precedent, ${ }^{225}$

tions and prejudices of local authorities," F. Frankfurter \& J. Landis, The Business of the Supreme Court 10 (1927) - also apply when the defendant seeks a stay in a $\$ 1345$ suit. See Colorado River Water Conservation Dist. v. United States, 424 U.S. 800,826 (1976) (Stevens, $J$., dissenting); $i d$. at $816 \mathrm{n} .23$ (reserving the question of whether abstention would ever be appropriate where the United States is a party in the federal suit). The issue will rarely arise, since the United States is not likely to sue as plaintiff in both federal and state courts, see H. Fruendly, Federal Jurisdiction: A General View 9 (1973), and must consent to be sued as defendant in state court, as in Colorado River.

${ }_{21 \times}$ See Columbia Note, supra note 104, at 705-06; Yale Note, supra note 92, at 984.

21' See, e.g., Aetna State Bank v. Altheimer, 430 F.2d 750, 758 (7th Cir. 1970); Mottolese v. Kaufman, 176 F.2d 301 (2d Cir. 1949).

220 Columbia Note, supra note 104, at 706; Yale Note, supra note 92, at 986-88. See note 92 supra.

221 See, e.g., Levy v. Alexander, 170 F. Supp. 439 (E.D.N.Y. 1959). See also note 198 supra.

${ }_{222}$ See Vestal, Repetitive Litigation, 45 Iowa L. Rev. 525, 535-36 (1960); Vestal, Reactive Litigation, 47 Iowa L. Rev. 11, 24 (1961).

23 In Applegate v. Devitt, 509 F.2d 106 (8th Cir. 1975), for example, the federal plaintiff resisted the defendant's stay motion on the ground that the defendant had brought the earlier state suit for the sole purpose of delaying the plaintiff's prosecution of his claim. After indicating his interest in a settlement the defendant filed suit in an Illinois state court, where a five year delay would have resulted if Applegate wished to have his counterclaim tried by a jury. The Eighth Circuit vacated the district court's stay order and remanded with instructions to consider the defendant's "bad faith "stalling' tactics" in ruling on its motion to stay. Id. at 109 .

${ }_{224}$ See, e.g., Weiner v. Shearson, Hammill \& Co., 521 F.2d 817, 820 (9th Cir. 1975); Aetna State Bank v. Altheimer, 430 F.2d 750, 756 (7th Cir. 1970); Amdur v. Lizars, 372 F.2d 103, 107 (4th Cir. 1967); Mottolese v. Kaufman, 176 F.2d 301, 303 (2d Cir. 1949).

${ }^{225}$ See, e.g., Weiner v. Shearson, Hammill \& Co., 521 F.2d 817, 821 (9th Cir. 1975); Aetna 
and analogies to situations in which stays do not result in the abrogation of federal jurisdiction. ${ }^{226}$ The Court's opinion in Colorado River implicitly disapproves that approach and emphasizes the federal courts' unflagging obligation to exercise the jurisdiction given them.

The exceptional circumstances standard requires the presence of a countervailing policy, or a principle guiding the exercise of the jurisdiction invoked, before a federal court may stay or dismiss the proceedings before it. This comment has suggested that such policies and principles can be found in the limitations on the removal of causes from state to federal courts and in the rules governing class action and derivative suits. The analysis has demonstrated that the exceptional circumstances required under Colorado River need not be limited to relatively unique policies like that which the Court identified in the McCarran Amendment; however, it has also shown that there are definite limits to the discretionary power of federal courts to decline jurisdiction. Stays can be an important means of regulating duplicative litigation and avoiding waste of judicial energies, but should not be used to deprive litigants of a federal forum absent strong reason in policy or principle for doing so.

Michael M. Wilson

State Bank v. Altheimer, 430 F.2d 750, 755 (7th Cir. 1970); Amdur v. Lizars, 372 F.2d 103, 106-07 (4th Cir. 1967); Mottolese v. Kaufman, 176 F.2d 301, 302-03 (2d Cir. 1949).

${ }_{226}$ See, e.g., Weiner v. Shearson, Hammill \& Co., 521 F.2d 817, 820 (9th Cir. 1975); Aetna State Bank v. Altheimer, 430 F.2d 750, 755-56 (7th Cir. 1970); Amdur v. Lizars, 372 F.2d 103, 106 (4th Cir. 1967); Mottolese v. Kaufman, 176 F.2d 301, 303 (2d Cir. 1949). 